\title{
Análise das unidades de paisagem e implicações socioambientais em áreas de preservação permanente nas regiões Nordeste e Sul do Brasil
}

Ingrid Carvalho Santos Oliveira $^{1}$ (D), Bruno Jandir Mello² (D), Cristiane Mansur de Moraes Souza ${ }^{3}$ (D), Patrícia Dornelles de Aguiar $^{2}$ (D), Cristiane Neyre Almeida de Jesus ${ }^{1}$ (D), Elaine Vasconcelos Nascimento Leal $^{3}$ (D), Jailton de Jesus Costa ${ }^{4}$ (D), Roberto Rodrigues de Souza ${ }^{5}$ (D), Rosemeri Melo e Souza ${ }^{6}$ (D)

\footnotetext{
${ }^{1}$ Programa de Pós-graduação em Desenvolvimento e Meio Ambiente, Universidade Federal de Sergipe (UFS), Prédio da Pólo de Pós-Graduação / Vivência, Cidade Universitária Prof. José Aloísio de Campos, Av. Marechal Rondon, s/n, Bairro: Jardim Rosa Elze, São Cristóvão/SE, 49100-000.

2 Programa de Pós-Graduação em Desenvolvimento Regional, Universidade Regional de Blumenau, Rua Antônio da Veiga, 140 - Itoupava Seca, Blumenau - SC, 89030-903.

${ }^{3}$ Programa de Pós-Graduação em Desenvolvimento Regional, Cursos de Arquitetura e Urbanismo e Engenharia Civil, Universidade Regional de Blumenau, Rua Antônio da Veiga, 140 - Itoupava Seca, Blumenau - SC, 89030-903.

${ }^{4}$ Universidade Federal de Sergipe. Líder do Grupo de Estudos e Pesquisas Interdisciplinares em Saúde, Gestão e Educação Ambiental - GESEA/CNPq/UFS, Cidade Universitária Prof. José Aloísio de Campos, Av. Marechal Rondon, s/n, Bairro: Jardim Rosa Elze, São Cristóvão/SE, 49100-000.

${ }^{5}$ Universidade Federal de Sergipe. Líder do Grupo de Pesquisa em Biotecnologia e Meio Ambiente (GPBIOMA/CNPq/ UFS), Cidade Universitária Prof. José Aloísio de Campos, Av. Marechal Rondon, s/n, Bairro: Jardim Rosa Elze, São Cristóvão/SE, 49100-000.

${ }^{6}$ Universidade Federal de Sergipe. Líder do Grupo de Pesquisa em Geoeocologia e Planejamento Territorial GEOPLAN/CNPq/UFS, Cidade Universitária Prof. José Aloísio de Campos, Av. Marechal Rondon, s/n, Bairro: Jardim Rosa Elze, São Cristóvão/SE, 49100-000.

*Autor para correspondência: jaicosta.se@gmail.com
}

Recebido em 14 de maio de 2020.

Aceito em 16 de dezembro de 2020.

Publicado em 31 de dezembro de 2020.

Resumo - As Áreas de Preservação Permanente (APP) são regulamentadas através da Lei Federal $\mathrm{n}^{\circ} 12.651 / 2012$. Essa Lei atua como instrumento regulador no processo de tomada de decisão para minimizar os problemas socioambientais, causados pelas diversas interferências antrópicas. Desta forma, esse artigo teve como objetivo geral analisar as unidades de paisagem em APP urbanas das cidades de Aracaju/SE e Blumenau/SC. Para construção desse estudo, foi elaborada uma análise comparativa entre trechos, de cada município, que apresentaram fortes ações antrópicas, sendo este o critério de escolha. Em Blumenau, utilizou-se como área de abrangência a da microbacia do Ribeirão Fresco; e em Aracaju, utilizou-se como área de abrangência a do rio Poxim. Os procedimentos metodológicos desse estudo foram ramificados em 3 etapas: revisão bibliográfica; visitas técnicas e sistematização dos dados, utilizando-se técnicas de Geoprocessamento, levantamento fotográfico e análise de documentos. Observou-se que nas duas regiões há problemáticas socioambientais semelhantes, a exemplo da ocupação (construções) em áreas destinadas às APP. Através dessas ocupações, as pressões antrópicas tornaram-se maiores, resultando em problemas como enchentes, deslizamentos de terra, descarte incorreto de resíduos sólidos, entre outros. Por fim, espera-se que, com os resultados apresentados, haja intervenção do poder público, nessas áreas protegidas juridicamente, com a formulação de políticas públicas efetivas, conservando a função socioambiental das APP.

Palavras-chave: APP; Interferências Antrópicas; Políticas Públicas; Problemas Socioambientais. 


\title{
Analysis of landscape units and socio-environmental implications in permanent preservation areas in the Northeast and South regions of Brazil
}

\begin{abstract}
Permanent Preservation Areas (APPs) are regulated through Federal Law No. 12. 651/ 2012. This Law acts as a regulatory instrument in the decision-making process to minimize socioenvironmental problems, caused by various anthropic interferences. Thus, this article aimed to analyze the landscape units in urban APPs in the cities of Aracaju / SE and Blumenau / SC. A comparative analysis for this study was carried out between inlands of each municipality. The criteria of choice of each chosen inland was important because it showed a strong anthropic action. The coverage areas were i) the Ribeirão Fresco watershed in Blumenau, and ii) the Poxim River in Aracaju. The methodological procedures of this study were divided into 3 stages: literature review; technical visits and data systematization, using Geoprocessing techniques, photographic survey and document analysis. It was observed that in both regions there were similar socio-environmental problems, such as the occupation (construction of buildings) in areas destined to APPs. Through them, anthropic pressures were increased, resulting in problems such as floods, landslides, incorrect disposal of solid waste, among others. Finally, it is expected that, with the results presented, there will be intervention by the public authorities in these legally protected areas, with the formulation of effective public policies, preserving the socio-environmental function of APPs.
\end{abstract}

Keywords: APPs; Anthropic Interference; Public Policies; Socio-environmental Problems.

\section{Análisis de unidades de paisaje e implicaciones socioambientales en áreas de preservación permanentes en el Noreste y regiones del Sur de Brasil}

Resumen - Las Áreas de Preservación Permanente (APP) se rigen por la Ley Federal n. ${ }^{\circ}$ 12.651/2012, que regula el proceso de toma de decisiones para reducir los problemas socioambientales causados por interferencias antrópicas. Por lo tanto, este artículo tuvo como objetivo analizar las unidades de paisaje en aplicaciones urbanas en las ciudades de Aracaju (Noreste de Brasil) y Blumenau (Sur de Brasil). Para la construcción de este estudio, se realizó un análisis comparativo entre tramos en cada municipio, que mostraron fuerte acción antrópica, siendo este el criterio de elección. En Blumenau, el área de cobertura utilizada fue la de la cuenca del Ribeirão Fresco. A su vez, en Aracaju, el área utilizada fue la del río Poxim. Los procedimientos metodológicos de este estudio se dividieron en tres etapas: revisión de la literatura; visitas técnicas y sistematización de datos, utilizando estrategias de geoprocesamiento, levantamiento fotográfico y análisis de documentos. Se observó que en ambas regiones existen problemas socioambientales similares, como construcciones en áreas de APP. A través de estas ocupaciones, las presiones antrópicas aumentaron, lo que resultó en problemas como inundaciones, deslizamientos de tierra, eliminación incorrecta de desechos sólidos, entre otros. Finalmente, se espera que, con los resultados presentados, las autoridades públicas intervengan en estas áreas legalmente protegidas, con la formulación de políticas públicas efectivas, preservando la función socioambiental de las APP.

Palabras clave: APP; Interferencia antrópica; Políticas Públicas; Problemas Socioambientales.

\section{Introdução}

As Áreas de Preservação Permanente (APP) são regulamentadas por Lei Federal, mas também são alvo de preocupação na construção dos Planos Diretores de Desenvolvimentos Urbanos (PDDU), 
dada a importância para a qualidade social, ambiental e econômica dos espaços. Neste contexto, a preservação das APP tem sido discutida em diferentes esferas da gestão urbana, envolvendo a sociedade civil organizada, Instituições de Ensino, Organizações Não Governamentais - ONGs, dentre outros sujeitos, com o objetivo de fomentar uma gestão que contemple a sustentabilidade urbana.

De acordo com Daiello e Rempel (2020 p.34), em consonância com a Lei 12.651/2012, que instituiu a Lei de Proteção à Vegetação Nativa, conhecida como Novo Código Florestal (BRASIL 2012), "são consideradas APP, em zonas rurais ou urbanas, entre outras localidades, as faixas marginais de qualquer curso d'água natural, as áreas no entorno de lagos, lagoas, nascentes, encostas com declividade superior a $45^{\circ}$, topo de morros e veredas".

Conforme o artigo 3ㄹ , II do Novo Código Florestal, "essas áreas, que visam proteger locais de grande importância ambiental, são essenciais para a conservação dos recursos naturais, manutenção da biodiversidade e para assegurar o bem-estar das populações humanas.

Embora o Novo Código Florestal tenha implementado uma redução direta na área da APP a ser protegida ao longo dos cursos d’água, já que as larguras das faixas de proteção passaram a ser contadas da calha do leito regular, e não mais de seu nível mais alto, como previa o Novo Código Florestal de 1965, os resultados do estudo de Daiello e Rempel (2020) demonstram que essa redução pode ser muito mais significativa.

As APP ligadas aos corpos d'água desempenham papéis ecológicos vitais, principalmente em relação à qualidade e à quantidade da água dos rios, dos córregos e dos ribeirões que compõem as bacias hidrográficas (Attanasio 2018). Devido à importância dessas unidades, existem legislações como Código Florestal (Lei Federal no 12.651 de 2012), e Resoluções 302, 303, 369 do Conselho Nacional do Meio Ambiente - CONAMA, que estabelecem regras de delimitação para essas áreas (Brasil 2002a, Brasil 2002b, Brasil 2006).

Tais instrumentos reguladores foram criados devido à interferência direta e indireta das ações antrópicas, que se intensificaram com o crescimento acelerado das cidades brasileiras, a partir do processo de industrialização que teve início em 1950, com destaque para as décadas de 1980 e 1990. Nesse contexto, corrobora-se com Facco, Fujita e Berto (2014, p.191), quando afirmam que "nas décadas de 1980 e 1990, as cidades brasileiras, de maneira geral, sofreram transformações rápidas, o que nos faz observar muitos problemas de cunho urbano e ambiental, como a ocupação urbana dispersa e precária em áreas sem infraestrutura e ambientalmente frágeis, a especulação imobiliária e a degradação ambiental, somados à carência de aplicação e fiscalização da legislação vigente e à ausência de políticas públicas eficientes.

Ainda acerca dessa discussão, Cantuário e Oliveira (2020, p.377-378) mencionam que "com o aumento do desmatamento na década de 1990, mesmo após a Rio-92, o Governo Federal foi provocado a tomar medidas mais rígidas nesse quesito, o que resultou na Lei dos Crimes Ambientais (LCA) n. 6.905, de 12 de fevereiro de 1998, reforçando o Código de 1965, mas que precisou ser alterada pelo Decreto n. 6.514, de 22 de julho de 2008, para incluir sanções de natureza administrativa e penal com efeito imediato.

Diante do exposto, merece destaque o estudo de Medeiros, Uliana e Araújo (2020), os quais enfatizam que "as áreas de preservação permanente têm sido ocupadas e degradadas pela expansão urbana sem planejamento". Desta forma, visando o processo de tomada de decisão, discute-se maneiras para minimizar ou mitigar os problemas ambientais decorrentes da ocupação em APP. Principalmente, tendo em vista que o estudo de Cantuário e Oliveira (2020, p.395) conclui que "nota-se que em 
decorrência dos vários aspectos citados a respeito de como as Áreas de Preservação Permanente no Brasil são tratadas tanto nas legislações específicas quanto pelo Poder Público competente e a sociedade civil, tem-se um panorama delicado que as compromete e ameaça sua existência”.

Torna-se necessário um planejamento urbano adequado para delinear as melhores ferramentas e ações a serem executadas para redução da problemática. Segundo Dias, Saad e Bau Dalmas (2020), o cenário ideal é o da fiscalização por parte da Defesa Civil municipal, não permitindo o inibindo as ocupações em áreas irregulares, logo no início do processo.

Diante do exposto, esse artigo teve como objetivo geral analisar as unidades de paisagem em APP urbanas das cidades de Aracaju/SE e Blumenau/SC, além de identificar as fragilidades existentes em todos os trechos estudados.

Foram determinados trechos específicos em cada Estado, com vistas a traçar um paralelo entre as unidades de paisagem a partir das interferências antrópicas nas APP. Em Aracaju, as APP a serem analisadas foram as do rio Poxim; e em Blumenau, as APP escolhidas foram as da microbacia hidrográfica do Ribeirão Fresco. Tais escolhas se deram a partir do critério de ocupação em APP e em ambas cidades, tendo em vista o projeto que fomentou esses resultados.

\section{Materiais e Métodos}

\section{Área de estudo}

O objeto de estudo dessa pesquisa são as APP. Para tanto, houve a escolha de áreas tanto na região Nordeste quanto na Sul (Figura 1). A escolha das áreas (Aracaju/SE e Blumenau/SC) partiu do pressuposto de que o alcance dos problemas dos dois recortes geográficos brasileiros: as ocupações de áreas de preservação permanente (APP) e as fragilidades existentes nos trechos, apresentam riscos sociais, ambientais e econômicos.

Figura 1. Localização das Cidades de Aracaju/SE e Blumenau/SC.
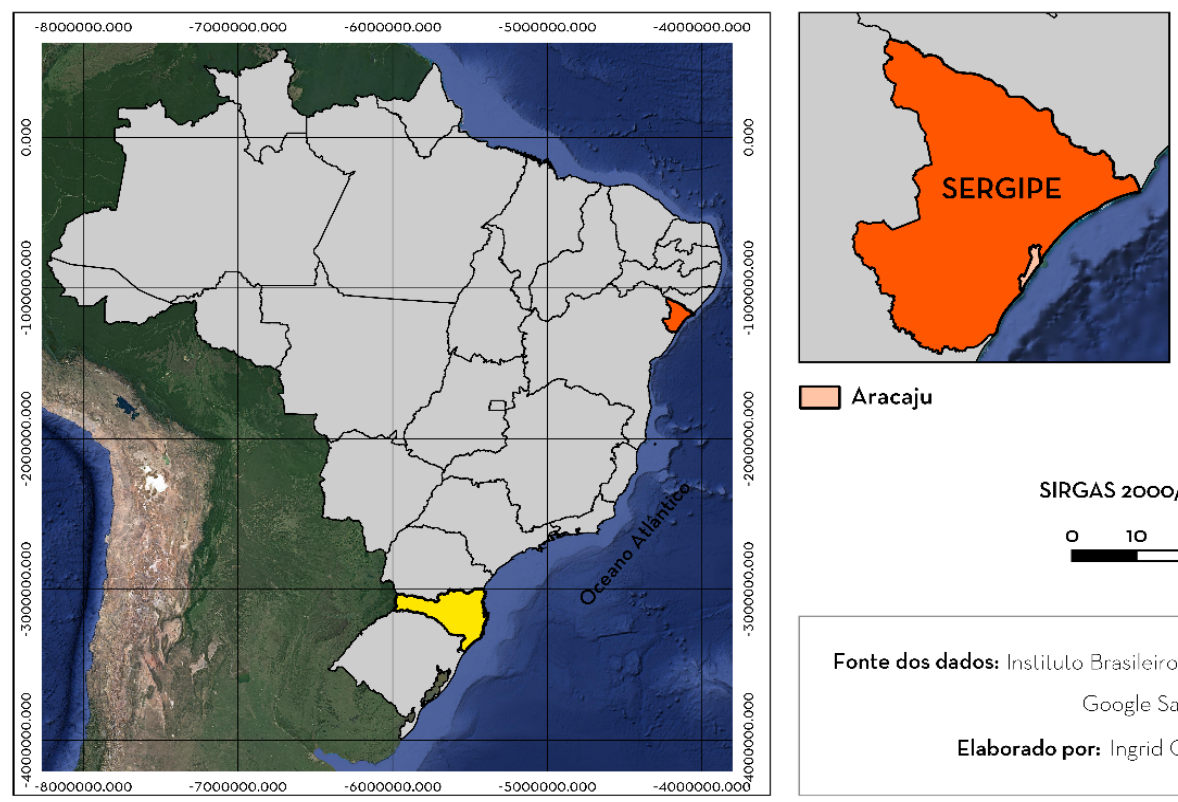

Aracaju
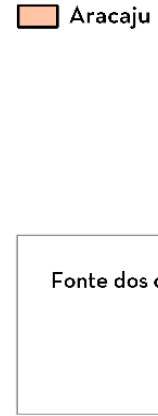

Estados do Brasil

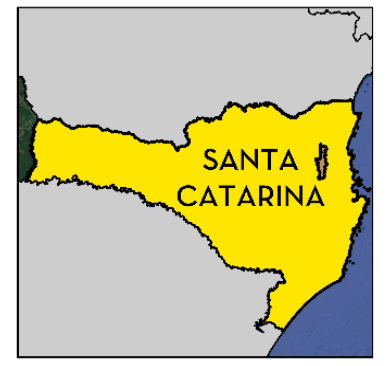

Blumenau

SIRGAS 2000/UTM ZONE 24S

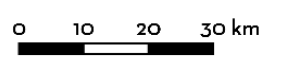

Fonte dos dados: Inslitulo Brasileiro de Geogralia e Estalística (IBGE), 2019. Google Satellite, 2020.

Elaborado por: Ingrid Carvalho Santos Oliveira, 2020. 
As cidades selecionadas estão localizadas em ambientes de planícies, sendo que Blumenau/ SC encontra-se localizada às margens do curso médio da bacia hidrográfica do rio Itajaí-Açu, sendo a terceira maior cidade de Santa Catarina, e considerada a cidade da região Sul do Brasil com maior risco de enchentes e inundações, enquanto Aracaju, capital do estado de Sergipe, situase defrontante ao estuário do rio Sergipe, na planície costeira sergipana, classificada com risco moderado de ocorrência dos mesmos fenômenos.

Área 1 - Microbacia de Ribeirão Fresco em Blumenau/SC

Em Blumenau/SC, utilizou-se como área de abrangência a microbacia do Ribeirão Fresco, que segundo Fernandes et al. (2020) "existe um indicador significativo de vulnerabilidade socioambiental". A microbacia apresenta distintos contextos socioespaciais, além de processos de ocupação e realidades peculiares. Está localizada próximo ao Centro do Município de Blumenau, área com maior diversificação de atividades econômicas e, consequentemente, de relevante desenvolvimento socioeconômico e cultural.

Ainda de acordo com Fernandes et al. (2020, p.1268), a microbacia do Ribeirão Fresco apresenta distintos contextos socioespaciais, além de processos de ocupação e realidades peculiares. Em geral, a área é formada por duas margens do estreito vale do Ribeirão Fresco. A urbanização ocupa grande parte das margens do Ribeirão e apresenta remanescentes de vegetação de Mata Atlântica secundária. A ocupação urbana regular do bairro Ribeirão Fresco está disposta num relevo de baixa altitude. Todavia, apresenta encostas com acentuada declividade, inclusive, ocupadas por residências.

A falta de planejamento territorial frente à necessidade do crescimento urbano ocasiona um péssimo aproveitamento sustentável da área de uma bacia hidrográfica, tanto na ótica ambiental quanto na econômica (Dias, Saad e Bau Dalmas 2020).

No entanto, o desenvolvimento urbano e econômico da cidade é limitado por recorrentes cheias e deslizamentos de terras que afetam a região. Por isso, a microbacia apresenta baixa número populacional, porém, grande número de assentamentos irregulares, pouca vitalidade e diversificação econômica. Na Microbacia, há três assentamentos irregulares, dois classificados como Zonas Especiais de Interesse Social pela Prefeitura Municipal de Blumenau, além de uma ocupação irregular recente. As dinâmicas neste território são muito complexas e os conflitos atingem todos os seus moradores. Sua área urbana apresenta $1,22 \mathrm{~km}^{2}$ e 1.359 habitantes (PMB 2013). Possui densidade populacional de 69,44 habitantes por hectare (IBGE 2010).

Os conflitos socioambientais do território da Microbacia do Ribeirão Fresco são resultado dá má gestão urbana e um quadro de marcantes desigualdades sociais (Fernandes et al. 2020).

Para Barbosa et al. (2017), a microbacia do Ribeirão Fresco está inserida em um contexto de múltiplas dinâmicas. É possível afirmar, que a ocupação humana modificou substancialmente a aludida região.

Área 2 - Microbacia do Rio Poxim em Aracaju/SE

Por sua vez, em Aracaju/SE, utilizou-se como área de abrangência o rio Poxim (Figura 2), que de acordo com a Agência Nacional de Águas - ANA (2019), é um dos rios urbanos responsáveis pelo abastecimento de água da capital sergipana. 
Figura 2. Localização da Microbacia do Rio Poxim e das Unidades de Paisagens (UPs).

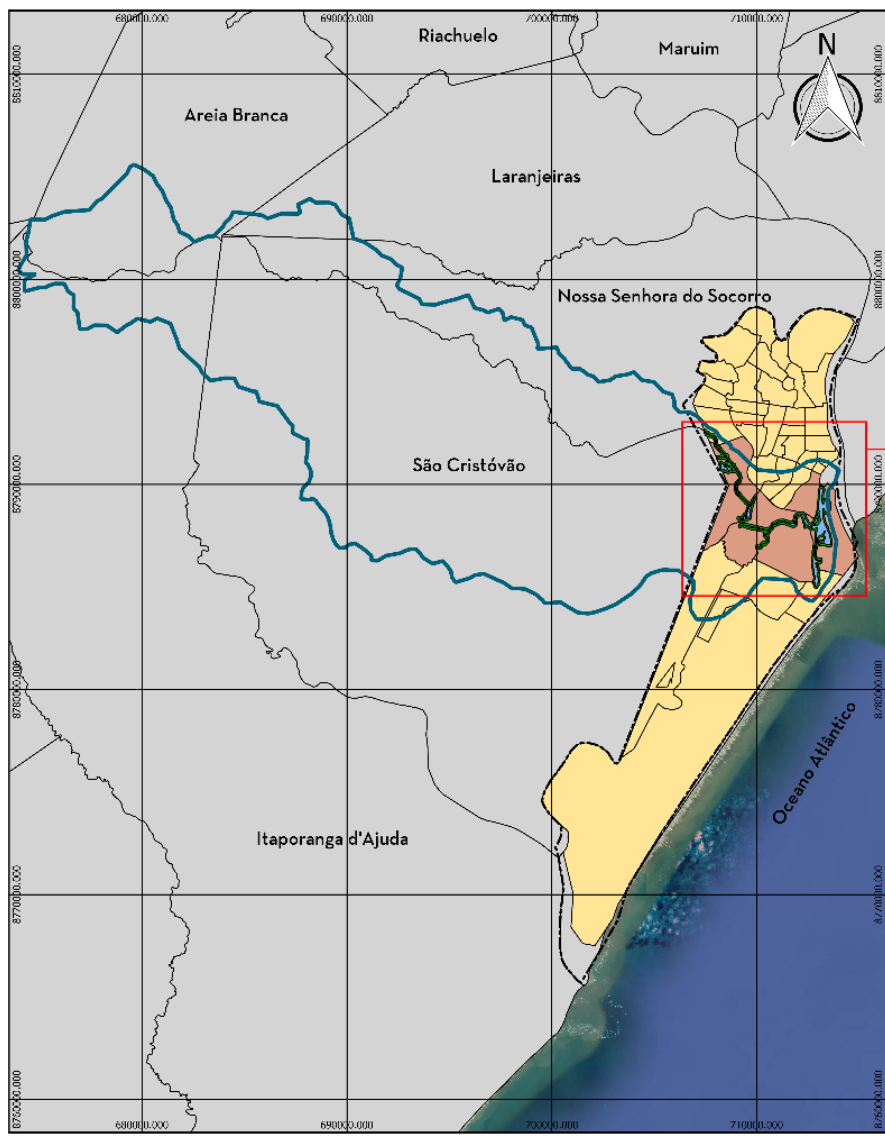

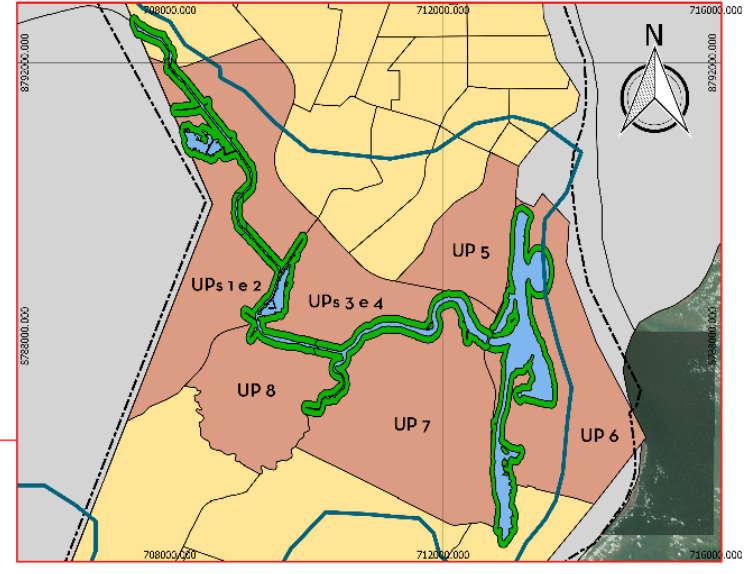

ÁREA DE ESTUDO - UNIDADES DE PAISAGEM (UPs)

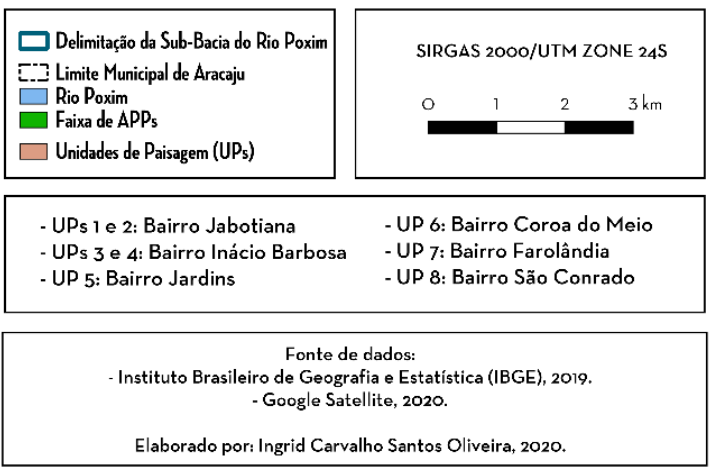

Em Aracaju, o estudo analisou as Unidades de Paisagem - UPs que o rio Poxim percorre e que sofrem impactos antrópicos nas suas APP. Através da Figura 2, notam-se as oito UPs e sua localização no curso do rio Poxim, no trecho de Aracaju.

De acordo com Santana et al. (2020) a microbacia do Rio Poxim possui "manguezal bem desenvolvido, mas os canais existentes servem como receptores finais de grande parte de esgotamento doméstico da região, assim como os despejos de resíduos sólidos sobre o rio Poxim.

Em sua área de nascente, predominam pequenas propriedades rurais e em seu curso médio, propriedades agrícolas, sendo as proximidades ocupadas por áreas residenciais e industriais. Quando o rio Poxim, em seu leito inferior atravessa o bairro Jabotiana em Aracaju, sofre um forte processo da ação antrópica, refletindo intenso impacto ambiental decorrente da expansão imobiliária, devido às construções de condomínios residenciais (horizontais e verticais). Tal ação ocasionou a devastação da mata ciliar, aterro do mangue, impermeabilização do solo, disposição inadequada de resíduos sólidos urbanos (resíduos domésticos e de construção civil) e despejo de efluentes domésticos (Araujo e Silva 2017).

Ainda segundo essas autoras, "com a construção de novos empreendimentos iniciou-se um forte processo de transformação da paisagem local. Contudo, houve uma valorização do solo urbano, atraindo um novo perfil de moradores, deixando a população ribeirinha excluída dessa nova configuração do bairro. Essas comunidades ribeirinhas até as últimas décadas faziam uso do rio para sobrevivência, através da pesca artesanal, além do lazer das famílias que residiam nas proximidades do rio". 
Segundo Ferreira et al. (2011), apesar de sua importância social e econômica, a sub-bacia hidrográfica do rio Poxim encontra-se em alto estado de degradação ambiental, principalmente no que se refere à supressão de sua vegetação ciliar. As atividades predominantes na região da subbacia do rio Poxim são do setor industrial (extrativismo mineral, construção civil, petróleo e gás natural, fertilizantes químicos, tecidos, dentre outras), sendo que os trechos finais dos rios Poxim e Pitanga localizam-se em áreas totalmente urbanizadas. A agropecuária também se destaca como importante atividade, com grandes propriedades de cana-de-açúcar. Já na região das nascentes, predominam pequenas propriedades, com destaque para a produção de milho, mandioca e feijão (Gonçalves e Gomes 2014).

Na parte de Aracaju, a microbacia hidrográfica do rio Poxim possui uma área de APP de 6,85 $\mathrm{km}^{2}$ (Oliveira 2020) e 125.973 habitantes (IBGE 2010). Portanto, possui densidade demográfica de 18.390 habitantes por $\mathrm{km}^{2}$, sendo a média de Aracaju 3.135 de acordo com os dados do IBGE (2010).

\section{Caminho operacional}

Os procedimentos metodológicos desse estudo foram classificados em 3 etapas: revisão bibliográfica; visitas técnicas e sistematização dos dados.

$\mathrm{Na}$ etapa da revisão bibliográfica, foram consultados artigos, dissertações e teses acerca das palavras-chave: recursos hídricos; APP; legislação (municipal, estadual e federal) ambiental; planejamento urbano, planejamento ambiental, gestão ambiental de áreas urbanas, dentre outras.

As bases de dados acadêmicos selecionadas foram Biblioteca Eletrônica Científica Online (Scielo), Google Acadêmico, Biblioteca Digital Brasileira de Teses e Dissertações (BDTD) e Portal Capes Periódicos.

Três critérios de exclusão foram selecionados: recorte temporal (artigos dos últimos cinco anos: 2015-2020, com exceção de Leis, Teorias e documentos oficiais, além de algumas informações do recorte espacial), idioma de publicação (português e inglês, de conhecimento dos autores) e relação direta com a temática desse estudo, ou seja, todos os estudos que não contemplassem esses três critérios, foram excluídos.

A avaliação da qualidade foi feita com base no Qualis Periódico da CAPES. Artigos inferiores a B2 na avaliação do quadriênio 2013-2016 e no Qualis Referência foram descartados. Os resultados foram inseridos no Excel e foi utilizada a ferramenta estatística descritiva.

$\mathrm{Na}$ etapa das visitas técnicas, as áreas de estudo foram percorridas a pé, por diversas vezes, com o objetivo de detectar e registrar as situações das APP e as problemáticas socioambientais existentes. Para comprovação e auxílio, foi realizado o registro fotográfico das áreas e marcação de pontos com Sistema de Posicionamento Global.

$\mathrm{Na}$ etapa sistematização de dados, foram organizados os dados coletados, o que possibilitou uma melhor compreensão do comparativo entre a situação das APP de Aracaju/SE e Blumenau/SC, além da construção dos cartogramas.

Para observar a dinâmica do trecho dessa microbacia do Ribeirão Fresco, foram escolhidas as cinco unidades de paisagem, definidas por meio de percepção/observação e a partir dos critérios ambientais (cobertura vegetal, relevo e hidrografia) e sociais (ocupação). A partir desses critérios, foi possível perceber transformações na paisagem, com a revelação de distintas dinâmicas e conflitos. 
Corrobora-se com Martins e Freitas (2014 p. 41) quando afirmam que "o estudo das UPs revela dados importantes para análises ambientais no que tange a questões relacionadas à preservação e à conservação.

No trecho escolhido em Blumenau, observou-se a paisagem construída e as APP. Para tanto, foram classificadas as seguintes unidades (Quadro 1).

Quadro 1. Unidades de Paisagem na Microbacia do Ribeirão Fresco.

\begin{tabular}{|c|l|}
\hline UP & \multicolumn{1}{|c|}{ TRECHOS } \\
\hline $\mathbf{1}$ & corresponde ao trecho da Igreja Luterana Espírito Santo até a escola Pastor Faulhaber. \\
\hline $\mathbf{2}$ & corresponde ao trecho da escola pastor Faulhaber até a entrada do "Camping". \\
\hline $\mathbf{3}$ & corresponde ao trecho do percurso pelo "Camping", na unidade de paisagem. \\
\hline $\mathbf{4}$ & corresponde ao trecho da Comunidade Garuva até o "Nevoeiro". \\
\hline $\mathbf{5}$ & $\begin{array}{l}\text { corresponde ao trecho conhecido como "Nevoeiro", uma nova área que teve aumento populacional significativo } \\
\text { nos últimos anos. }\end{array}$ \\
\hline
\end{tabular}

Organização: Jailton de Jesus Costa, 2020.

Para observar a dinâmica da bacia do Rio Poxim, oito unidades de paisagem (Quadro 02), foram definidas por meio de percepção/observação e a partir dos critérios ambientais (cobertura vegetal, relevo e hidrografia) e sociais (ocupação), com destaque para os sociais no curso do rio Poxim, trecho de Aracaju/SE.

Quadro 2. Unidades de Paisagem na Microbacia do rio Poxim, em Aracaju/SE.

\begin{tabular}{|c|l|}
\hline UP & \multicolumn{1}{|c|}{ TRECHOS } \\
\hline $\mathbf{1}$ & $\begin{array}{l}\text { corresponde ao trecho com edificações verticais multifamiliares em áreas de APP, localizadas no bairro } \\
\text { Jabotiana. }\end{array}$ \\
\hline $\mathbf{2}$ & $\begin{array}{l}\text { corresponde ao trecho com condomínios do Programa de Arrendamento Residencial - PAR e residências } \\
\text { com condições precárias de infraestrutura. }\end{array}$ \\
\hline $\mathbf{3}$ & $\begin{array}{l}\text { corresponde ao trecho da comunidade Pantanal, com ruas sem pavimentação e a delimitação entre o } \\
\text { ambiente construído e natural se dá por um pequeno muro de contenção. }\end{array}$ \\
\hline $\mathbf{4}$ & $\begin{array}{l}\text { corresponde ao trecho com edificações residenciais de classe média, compreendendo os outros conjuntos } \\
\text { residenciais existentes. }\end{array}$ \\
\hline $\mathbf{5}$ & $\begin{array}{l}\text { corresponde ao trecho com maior grau de urbanização e estruturação de Aracaju, com edificações } \\
\text { residenciais de alto padrão de construção. }\end{array}$ \\
\hline $\mathbf{6}$ & $\begin{array}{l}\text { corresponde ao trecho bastante heterogêneo, principalmente no tocante às condições de renda da população } \\
\text { residente. Caracterizado por residenciais unifamiliares e espaços públicos deteriorados. }\end{array}$ \\
\hline $\mathbf{7}$ & corresponde ao trecho em que os muros dos condomínios verticais impendem o acesso as APP. \\
\hline $\mathbf{8}$ & $\begin{array}{l}\text { corresponde ao trecho com a pior infraestrutura das edificaçães. Carência de áreas de recreação e lazer e } \\
\text { lançamento de efluentes diretamente no rio Poxim. }\end{array}$ \\
\hline
\end{tabular}

Organização: Jailton de Jesus Costa, 2020.

Por sua vez, para a construção da síntese das fragilidades existentes nos trechos de Blumenau/ SC e Aracaju/SE, foi necessário o estudo de indicadores, a partir da realidade encontrada em cada unidade de paisagem. De acordo com Dias, Trentin e Sccoti (2015), "as fragilidades e as potencialidades da paisagem, podem ser estudadas tanto no limite de uma bacia hidrográfica, 
quanto no limite de um município ou até mesmo uma unidade de federação, desde que consiga estabelecer uma correlação entre o uso e a ocupação e a geomorfologia.

Para a análise da fragilidade, exige-se que esses conhecimentos setorizados sejam avaliados de forma integrada, calcada sempre no princípio de que, na natureza a funcionalidade é intrínseca entre as componentes físicas, bióticas e socioeconômicas (Guerra e Cunha 1966 apud Ferreira, Ferreira e Gouveia 2016).

No caso de Aracaju, foi possível avaliar o índice de uso e ocupação do solo, a partir da seguinte fórmula, proposta por Oliveira (2020).

$$
\text { IUOS }=\frac{A C}{\text { TAAPP }} \times 100
$$

Em que:

$\mathrm{AC}=$ Área Construída em APP.

TAAPP $=$ Total da Área de APP.

\section{Resultados e Discussões}

\section{Análise dos trechos de Blumenau/SC}

Para analisar as cinco unidades de paisagem da microbacia de Ribeirão Fresco, construiu-se o mapa apresentado na Figura 3.

Figura 3. Áreas de Preservação Permanente e unidades de paisagem em Blumenau/SC.

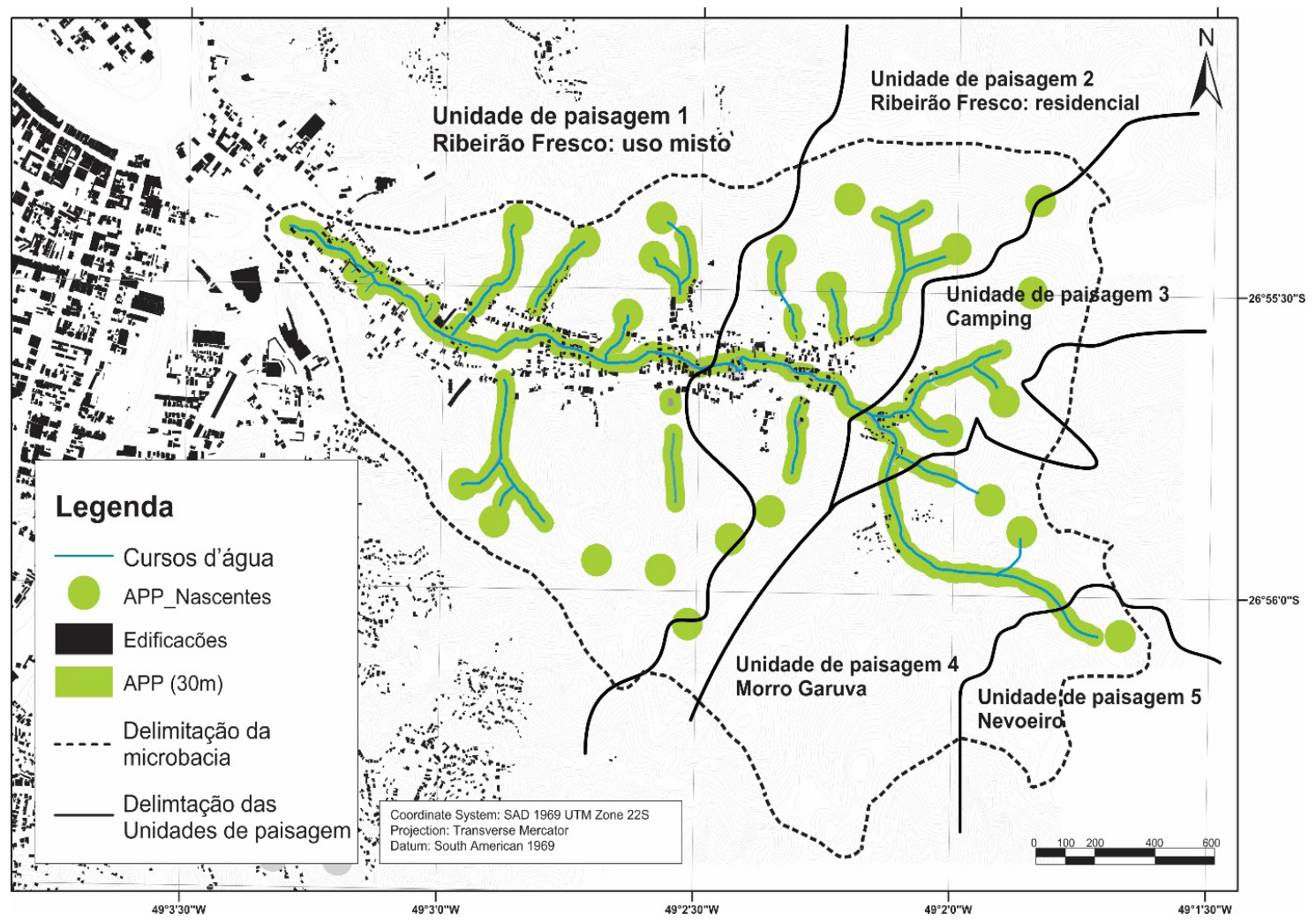

Organização: Bruno Jandir Mello, Cristiane Mansur de Moraes Souza e Patrícia Dornelles de Aguiar, 2019.

Fonte: Adaptado da base cartográfica do município de Blumenau (Blumenau, 2010). 
Unidade de Paisagem 1

Inicia-se em dos principais patrimônios arquitetônicos do município, a Igreja Luterana Espirito Santo. Nos primeiros metros da Rua Pastor Oswald Hesse (Figura 4) é possível observar a íngreme topografia da região, ao lado direito pelas colinas e ao lado esquerdo, pelo ribeirão que dá nome ao bairro. Pressionadas por estas condicionantes, há três residências históricas de arquitetura vernacular de tijolos do começo do século XX (Figura 4A).

A cidade, nascida na foz do ribeirão da Garcia, afluente do rio Itajaí-açú, foi colonizada por alemães a partir de 1850 e há 165 anos vem se construindo em um sítio físico com características bastante específicas em função de sua situação de vale. Com uma formação inicial derivada dos lotes estreitos e compridos definidos pelo traçado colonial, Blumenau se expandiu lentamente entre os morros e os rios (Carminatti 2016).

Segundo Camargo (2018), "os alemães adentraram o território e o dividiram em lotes onde foram edificadas as primeiras moradias da colônia, usando a técnica enxaimel, característica arquitetônica marcante em Blumenau. Para Oliveira (2011), a técnica enxaimel, "consiste em uma trama de madeira aparelhada com peças horizontais, verticais e inclinadas, que em sua construção vão formando paredes estruturadas e encaixadas entre si. Posteriormente, estes quadros ou tramas são preenchidos com taipa, tijolos, adobe ou pedra".

Adiante, após um conjunto de ocupações recentes, outro exemplo da arquitetura histórica da cidade: uma pequena casa de arquitetura historicista. Seguindo entre vazios urbanos, casas modernas e antigas, o que lembra uma pequena cidade de interior, chega-se no ápice da arquitetura histórica da microbacia, a casa do arquiteto Egon Belz (Figura 4B), importante representante da arquitetura moderna em Blumenau.

Figura 4. Conjunto Arquitetônico Histórico na Rua Pastor Oswald Hesse.

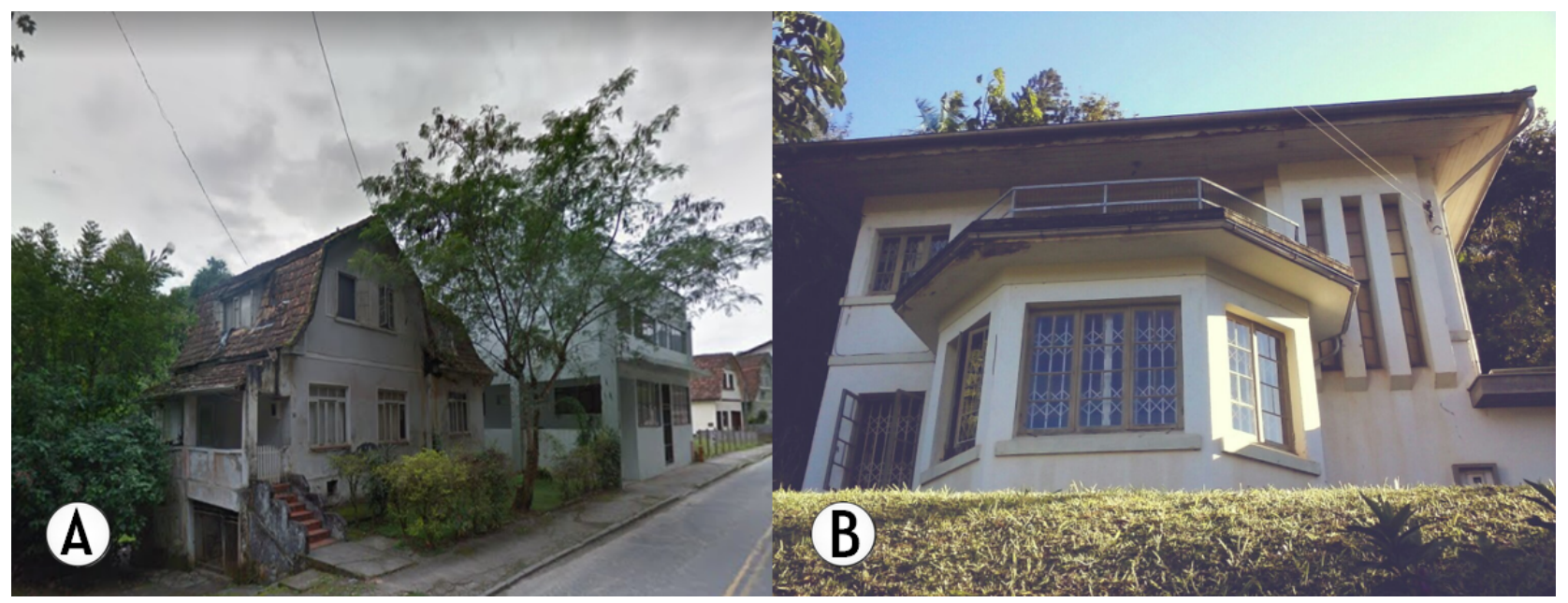

Fonte: Visita técnica, 2019.

Conforme segue o percurso dessa UP, as casas históricas tornam-se cada vez mais raras, enquanto as casas de arquitetura contemporânea são mais frequentes, sendo que estas não possuem preocupações com as condicionantes ambientais. Ao final do percurso de $2 \mathrm{~km}$, ao lado esquerdo, há um pequeno mercado em uma antiga casa de dois pavimentos, a qual foi inspirada na arquitetura 
Art Decó. Ao lado direito, entre casas históricas de arquitetura vernacular, há um dos primeiros edifícios da região, intitulado de Residencial Ecovilla.

O que se pode perceber é que este trecho apresenta uma boa infraestrutura, sendo a região mais valorizada da comunidade. Há comércios e serviços que geram empregos; e parte da arquitetura histórica encontra-se nesse percurso. Percebe-se três planos horizontais nessa primeira UP.

O primeiro plano horizontal é o ribeirão, este definiu a forma como se a locomoção e ocupação do espaço. O ribeirão tem origem nos divisores de água, no alto do morro Garuva e desagua no Ribeirão Garcia, desembocando no Rio Itajaí-açu. A vegetação é de mata ciliar secundária. O ribeirão tende a transpassar o segundo plano, Rua Pastor Oswald Hesse, se tornando um único plano (Figura 5).

Figura 5. Planos Horizontais na Unidade de Paisagem I.

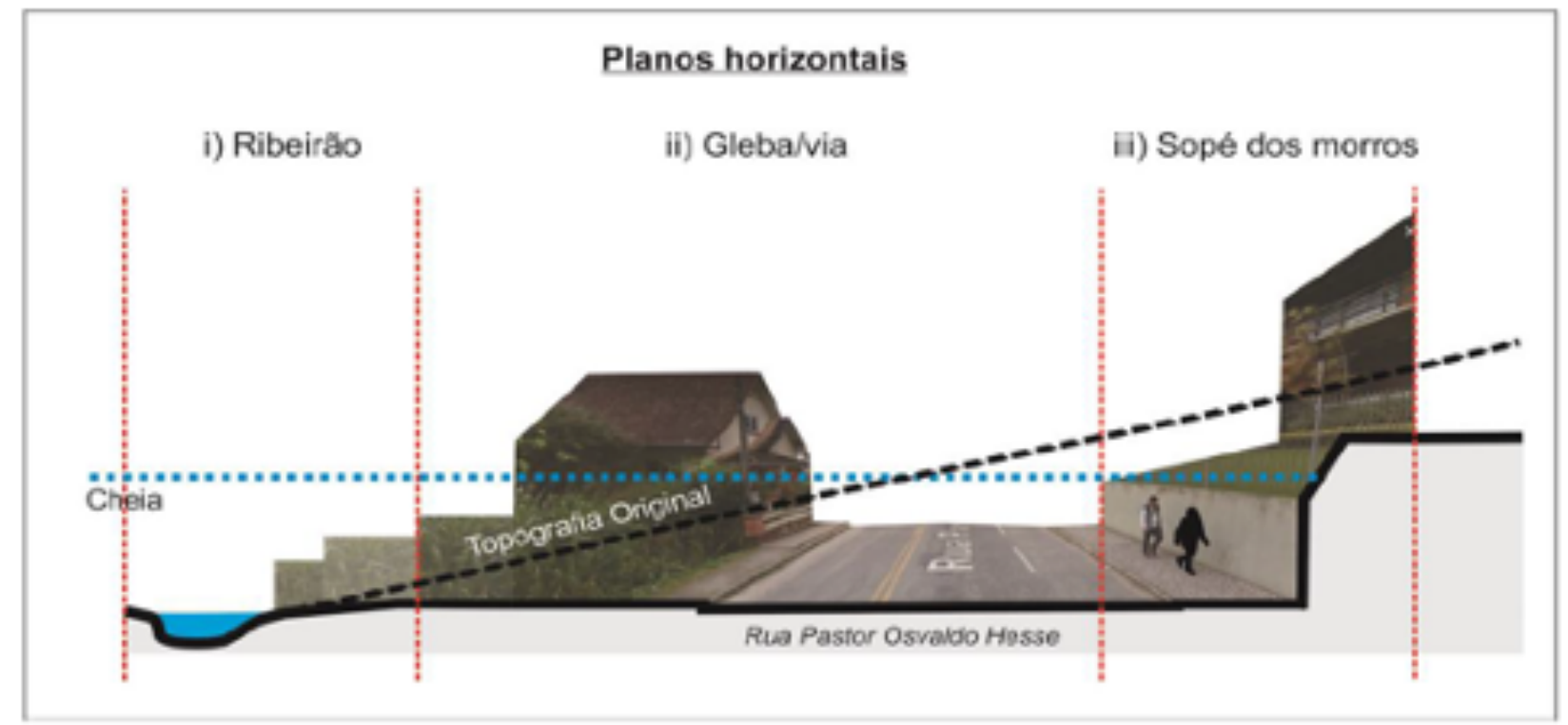

Organização: Bruno Jandir Mello, 2019.

A segunda horizontalidade invade as planícies de inundação e esbarra em extensos cortes na topografia. Esta é constituído pelas terraplenagens das glebas e a Rua Pastor Oswald Hesse. Este plano esbarra em verdadeiros muros que impedem o fluxo natural das cheias. $\mathrm{O}$ terceiro plano horizontal é a modificação do sopé do morro, construído como estratégia de prevenção das enchentes. As casas mais valorizadas e antigas estão implantadas nesta margem. Assim, chega-se no segundo marco, a Escola Básica Municipal Pastor Faulhaber.

Pode se notar também que as residências acima da colina possuem melhor infraestrutura e são mais valorizadas, em contraponto às edificações que estão localizadas entre ribeirão-via-colina. Porém, estas têm o melhor potencial para o uso comercial, pois está na escala humana, mantendo a tipologia de dois pavimentos como prevenção de cheias.

Unidade de Paisagem 2

Essa segunda UP assemelha-se com a UP anterior, porém, pode-se identificar um declínio das condições sociais e uma predominância do uso residencial. Primeiramente, é percorrido pela 
Escola Básica Municipal Pastor Faulhaber e o Centro de Educação Infantil Professora Teresa de Araújo (Figura 6).

Figura 6. Equipamentos urbanos na Unidade de Paisagem 2.

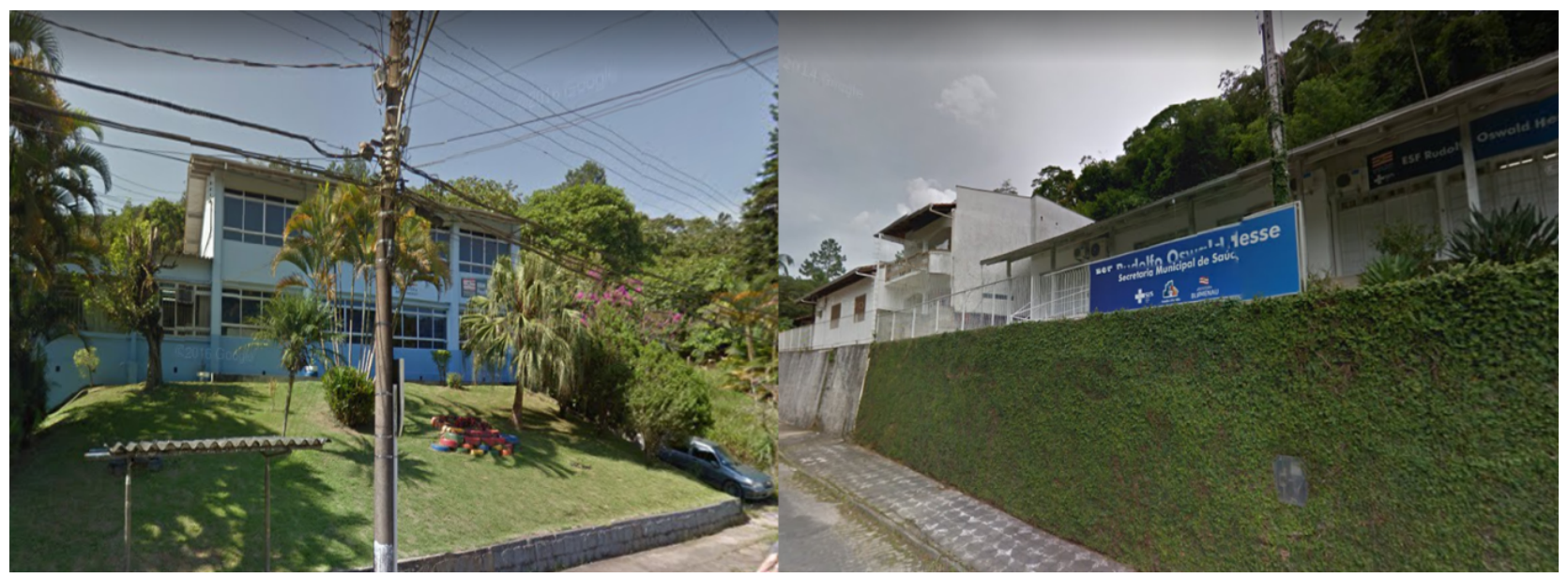

Ao lado da escola há um terreno abandonado, que no passado era uma residência histórica, mas que foi demolida e substituída por uma igreja de pequeno porte. Há a ocorrência de diversos vazios urbanos e é perceptível a mudança de inclinação das encostas, nesta área o vale fecha-se, limitando a visão do transeunte. É possível identificar um conjunto de residências dos anos 1930 e 1950, em menor quantidade, comparado ao primeiro trecho. Também é possível identificar casas recentes com boa infraestrutura. A 200 metros da escola, as cheias atuais não atingem mais o local e, neste ponto, as residências alternam de alto, médio e baixo padrão.

Em direção às comunidades, as residências mesclam entre boa e baixa infraestrutura. As melhores residências ainda mantêm o padrão do primeiro percurso, nos sopés dos morros. Enquanto as menores, estão dispostas em áreas de cheias e enxurradas. Chega-se ao clube de escoteiros Leões, que é um abrigo para caso de desastres, nesse trecho, ocorre uma mudança de pavimentação, uma vez que, o que era asfalto, torna-se blocos octogonais de concreto. Saindo da Rua Pastor Oswald Hesse e indo para a Rua Henrique Ave Lallemant, há um estreitamento da estrada e as casas mantêm um padrão de baixo gabarito de altura, com lotes mais estreitos. Neste trecho, pode ser identificada uma residência histórica, datada de 1950 . Assim, encontra-se uma bifurcação que ao entrar à esquerda é o acesso ao "Camping", e à direita, é o acesso à comunidade Garuva.

Nessa UP, o vale fecha-se por completo, configurando o final das áreas baixas da microbacia. Nas UPs 1, 2 até a 3 (Figura 7), as unidades paisagísticas contemplam ribeirão, casas, vias, casas no sopé do morro, além de vegetação em aclive e topo do morro. Também há uma unidade de composição construída.

A maioria das casas são de um a três pavimentos, com telhados de cerâmica em diversas vias estreitas. Há uma predominância de uso de solo residencial. Nesta área, as vias são pavimentadas por asfalto e blocos, há coleta de lixo, água encanada, energia elétrica, disponibilidade de transporte coletivo em diversos horários, equipamentos urbanos e drenagem urbana. 
Figura 7. Paisagem do "Camping".

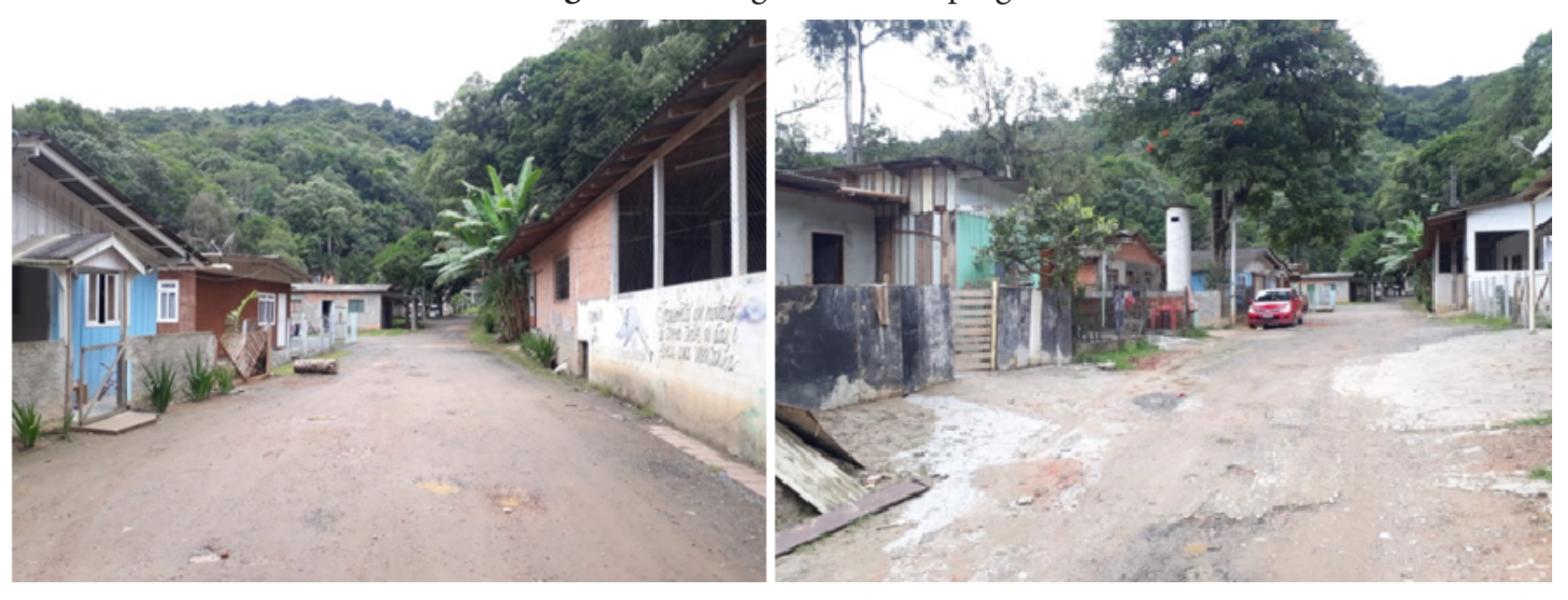

Até esse ponto, pode-se afirmar que ação da "cidade formal" e de certo ponto planejada, formou uma área com melhores condições para a ocupação. A partir desse ponto, tem início as áreas informais da microbacia, com destaque para a morfologia desses espaços socialmente excluídos.

\section{Unidade de Paisagem 3}

A unidade de paisagem 3 é marcada pelo fechamento do vale, responsável por ocultar conflitos socioespaciais importantes. Por um caminho de estrada de terra, seguiu-se em direção ao "Camping" que é um conjunto de habitações populares, derivado de uma ocupação de terras públicas, que ocorreu no pós-desastre de 2008, em que milhares de pessoas ficaram desabrigadas devido aos deslizamentos de terras. Devido à problemática apresentada, ativistas sociais e políticos formaram o movimento MAD (Movimento dos Atingidos pelos Desastres). Através deste movimento, terras públicas de um "Camping” foram apropriadas e utilizadas como área de lazer pelos moradores do bairro. A maioria dos habitantes do "Camping" recebeu esses terrenos após um sorteio realizado pelos membros do MAD. Dando continuidade ao trecho, percebe-se que a paisagem muda radicalmente, principalmente quanto a infraestrutura urbana, critério definidor dessa unidade.

As condições de infraestrutura são precárias, estrada de terra; vias sem passeios, drenagem a céu aberto e esgotos lançados sem qualquer tratamento. A maioria das casas é de madeira e poucas de alvenaria. Encontra-se um equipamento urbano que é a Associação de Moradores e no trecho que o vale fecha-se por inteiro é possível identificar novas ocupações nos talvegues. Ao fundo, notase a presença de uma cachoeira, onde há um pequeno quiosque de uso comum da comunidade. A esquerda, por uma rua sem nome, observa-se os fundos das casas com os encanamentos de água e esgotos, sem tratamento, direcionados para o ribeirão, e após um longo trecho de vegetação fechada, encontra-se mais uma ocupação de casas consolidadas. A região do "Camping" é classificada pela prefeitura como uma Zona Especial de Interesse Social (ZEIS), porém os conflitos pela regularização dos terrenos e da melhoria da infraestrutura parecem intermináveis. 
Unidade de Paisagem 4

A UP 4 corresponde a paisagem da comunidade Garuva até o "Nevoeiro" (Figura 8). Do "Camping" até a Garuva, faz-se um longo percurso por estrada de terra em aclive, com a vegetação densa mascarando o campo de visão. A partir da última curva a direita, surge na paisagem, como em um paredão de madeira e alvenaria, a comunidade Garuva. Delimitada pelo ribeirão, ascende-se ao topo do morro Garuva com ocupações extremamente precárias. As casas nas encostas sobrepõemse uma a uma e é o mais próximo que se aproxima de uma favela de uma grande metrópole. $\mathrm{O}$ acesso para as casas nas encostas é realizado através das escadarias, que funcionam como elevadores, uma vez que não há vias de acesso às casas. A vegetação permeia as ocupações irregulares, junto com fiações aéreas irregulares e canos de captação de poços artesianos e nascentes. O assentamento é precário e de alto risco de deslizamento de terra, devido à retirada da vegetação para ocupação.

Figura 8. Comunidade Garuva na Unidade de Paisagem 4.

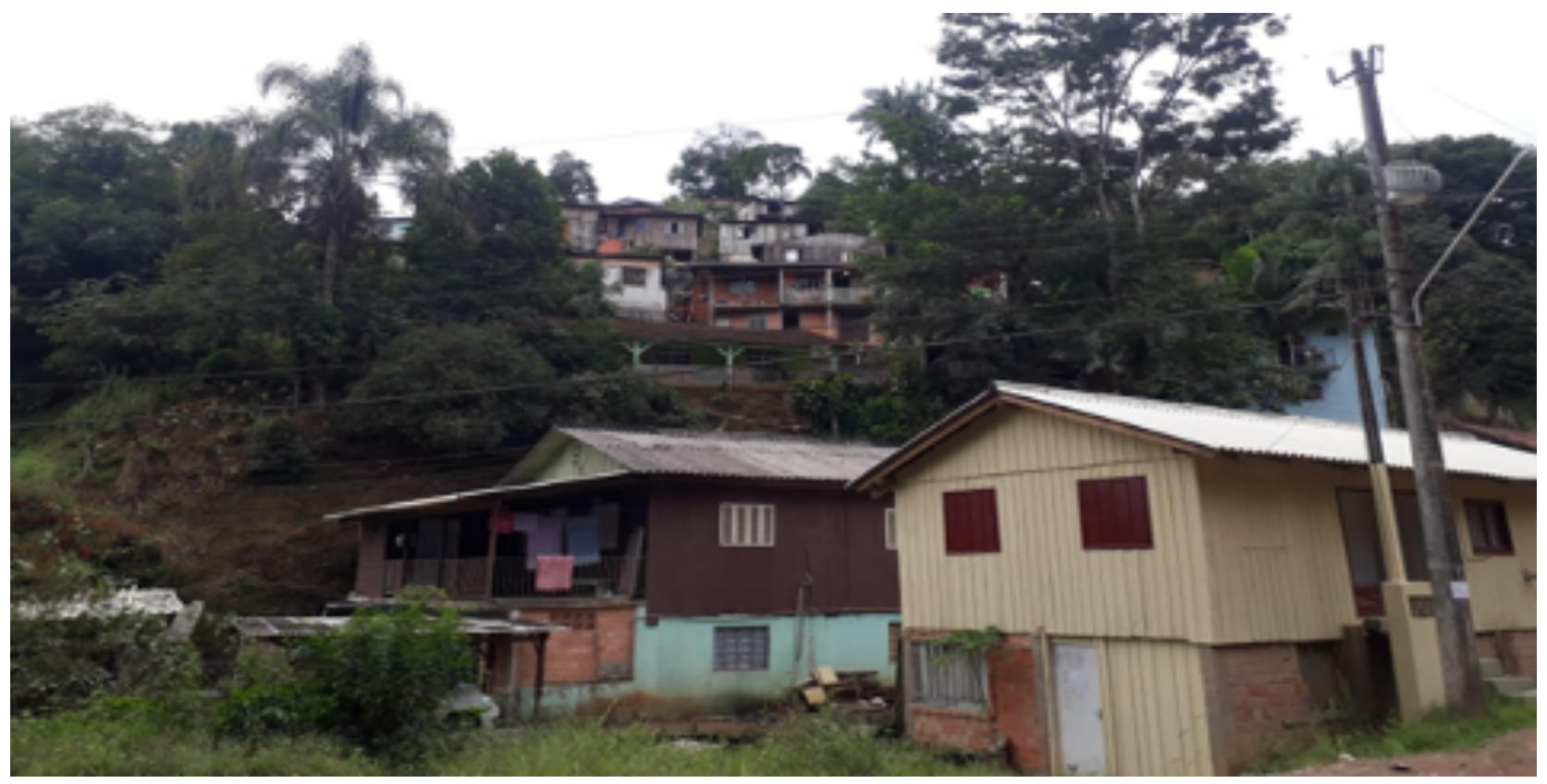

Fonte: Visita técnica, 2019.

A comunidade Garuva, habitada atualmente por 140 famílias, tem condições de infraestrutura e saneamento básico precárias. A população da área sofre com altos índices de doenças relacionadas à falta de qualidade da água distribuída, pois não há água encanada e nem tratamento de esgotos. As condições socioeconômicas também são degradantes, a maioria da população ganha em média de 1 a 3 salários-mínimos (Mello 2019).

O uso é predominantemente residencial, e não são registrados comércios e serviços formais. Os poucos serviços existentes, são de caráter informal, como pedreiros e costureiras. A Rua Benigno Joaquim dos Santos não é pavimentada e não há passeios públicos. Há a fragilidade do transporte público devido a poucos horários disponíveis de linhas de ônibus, e a coleta de resíduos sólidos é realizada apenas uma vez por semana. Essa área, a exemplo do "Camping", é classificada como ZEIS e há intensos conflitos pela regularização fundiária e melhorias da qualidade de vida dos moradores. 


\section{Unidade de Paisagem 5}

Essa última unidade refere-se à região conhecida popularmente por "Nevoeiro". Esse local é habitado, atualmente, por 30 famílias e localiza-se na Rua Benigno Joaquim dos Santos. O processo de ocupação iniciou-se há aproximadamente 20 anos, através da construção de algumas residências e sítio. Em 2015, através da ocupação irregular de um terreno pertencente ao senhor Rui Willick, ocorreu o desmembramento e venda de lotes. Com isso, houve um elevado aumento populacional na área. A região possui uma ocupação predominantemente residencial, de baixa renda e no topo do morro, implicando na retirada da vegetação original (Figura 9).

Figura 9. Região conhecida como "Nevoeiro".

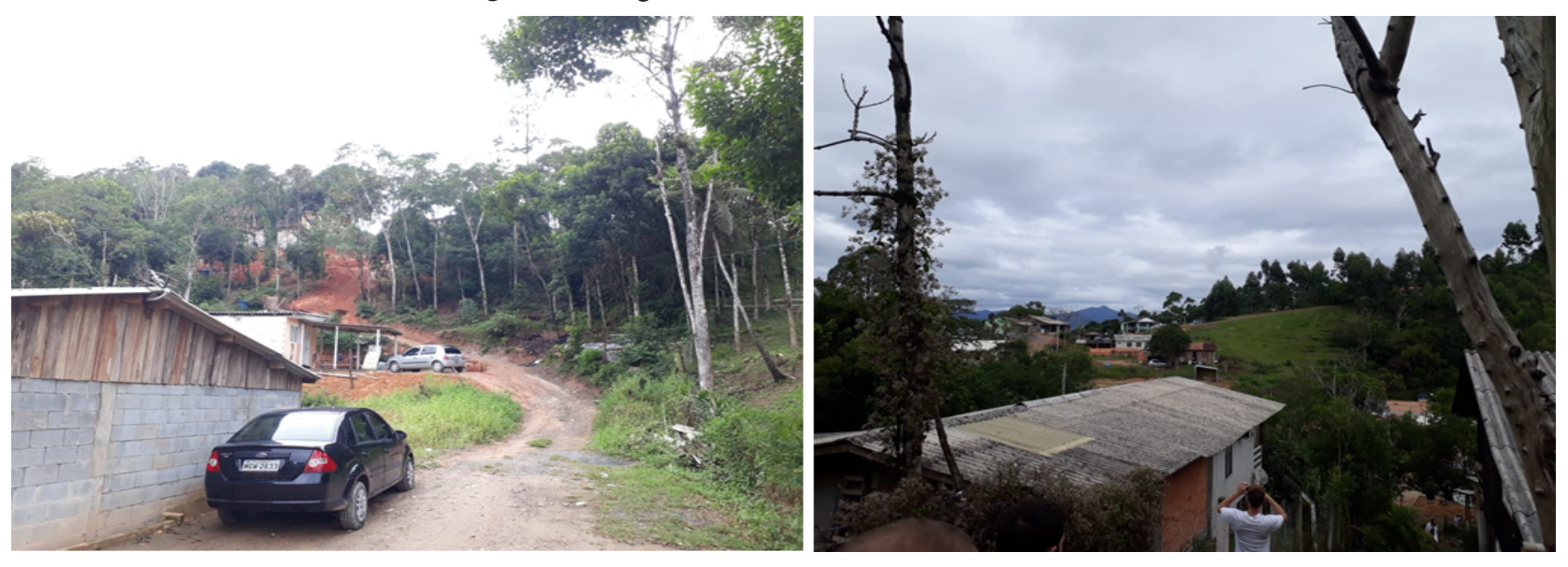

Fonte: Visita técnica, 2019.

Não há calçamento nas ruas, o transporte público é disponibilizado quatro vezes por dia, a coleta de resíduos sólidos é semanal, não há água encanada e nem tratamento de efluentes. No local, não áreas de lazer ou equipamentos urbanos próximos. As moradias são de madeira aparelhada e alvenaria sem acabamento.

Em relação a tipologia do uso e ocupação do solo, no local há dois bares e duas "chácaras" (há criação de cavalos, galinhas e porcos). A maioria dos moradores são migrantes brasileiros, principalmente do Nordeste e Sul do país. A comunidade, apesar de pouco articulada com órgãos públicos e privados, é engajada, pois entenderam a necessidade de unir os moradores para debater coletivamente os problemas, a exemplo das reivindicações, a órgãos públicos, referentes às solicitações de água encanada e usucapião de lotes.

\section{Análise dos trechos situados em Aracaju/SE}

\section{Unidades de Paisagem 1 e 2}

Essas unidades se localizam no bairro Jabotiana, por onde se iniciou o percurso das APP do rio Poxim, sendo resultado das consequências da especulação imobiliária, cujo resultado é perceptível através das diferentes características tipológicas existentes (edificações horizontais unifamiliares e edificações verticais multifamiliares). Essa especulação imobiliária é responsável por consequências 
negativas no meio ambiente, principalmente através de pressões antrópicas. O primeiro exemplo a ser destacado, em relação às pressões, é o das modificações no ambiente natural (supressão das APP) através da construção de edificações em diferentes trechos do bairro. O primeiro registro fotográfico, dessa unidade, consiste no trecho cujas edificações são exclusivamente verticais (Condomínio Bellagio Residence, Privillege e Bossa Nova) conforme a Figura 10.

Figura 10. Condomínios situados em APP na Unidade de Paisagem 1.

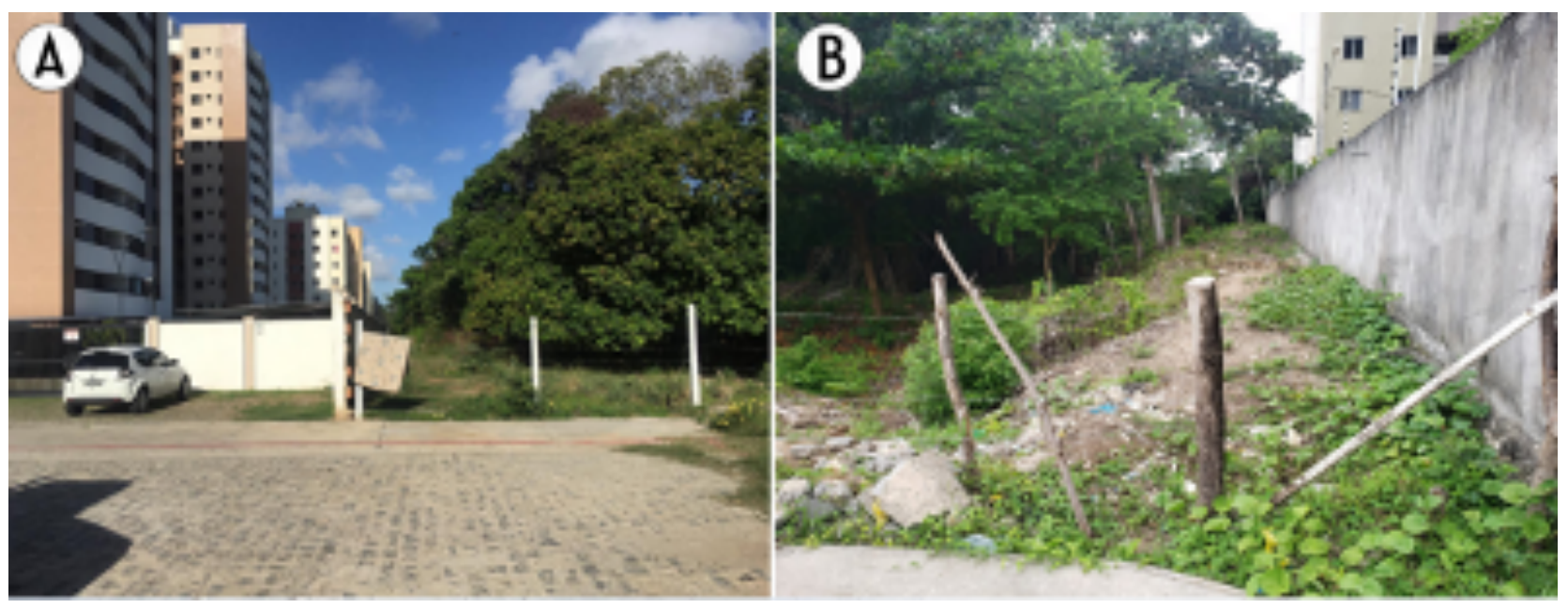

Fonte: Visitas técnicas, 2020.

A supressão das APP, através da construção dessas edificações, implica em outros problemas existentes na unidade de paisagem, pois o adensamento da área, sem o devido planejamento, provoca problemas como efluentes lançados diretamente no rio Poxim, UP2 (Figura 11A) e descarte incorreto de resíduos sólidos (Figura 11B), na UP 1.

Desta forma, percebe-se que rio Poxim sofre interferência de diversos fatores antrópicos que implicam na poluição dele. Exemplos disso são os processos de degradação, devido ao lançamento direto de esgoto sem tratamento; despejo de resíduos sólidos e o desmatamento de matas ciliares, conforme foi registrado nas 06 visitas técnicas realizadas. Esses fatores citados geram consequências como assoreamento do rio e perda da biodiversidade.

De acordo com Oliveira et al. (2020) nem sempre são respeitados os limites mínimos para Áreas de Preservação Permanentes (APP's), pois o processo de urbanização e criação de áreas agrícolas resultam em pressões antrópicas diversas no ambiente de mata ciliar. Este processo de degradação das formações ciliares, além de desrespeitar a legislação, que torna obrigatória a preservação delas, resulta em vários problemas ambientais, como por exemplo, o aumento da turbidez do corpo hídrico. 
Figura 11. Registro de problemas existentes nas Unidades de Paisagens 1 e 2.

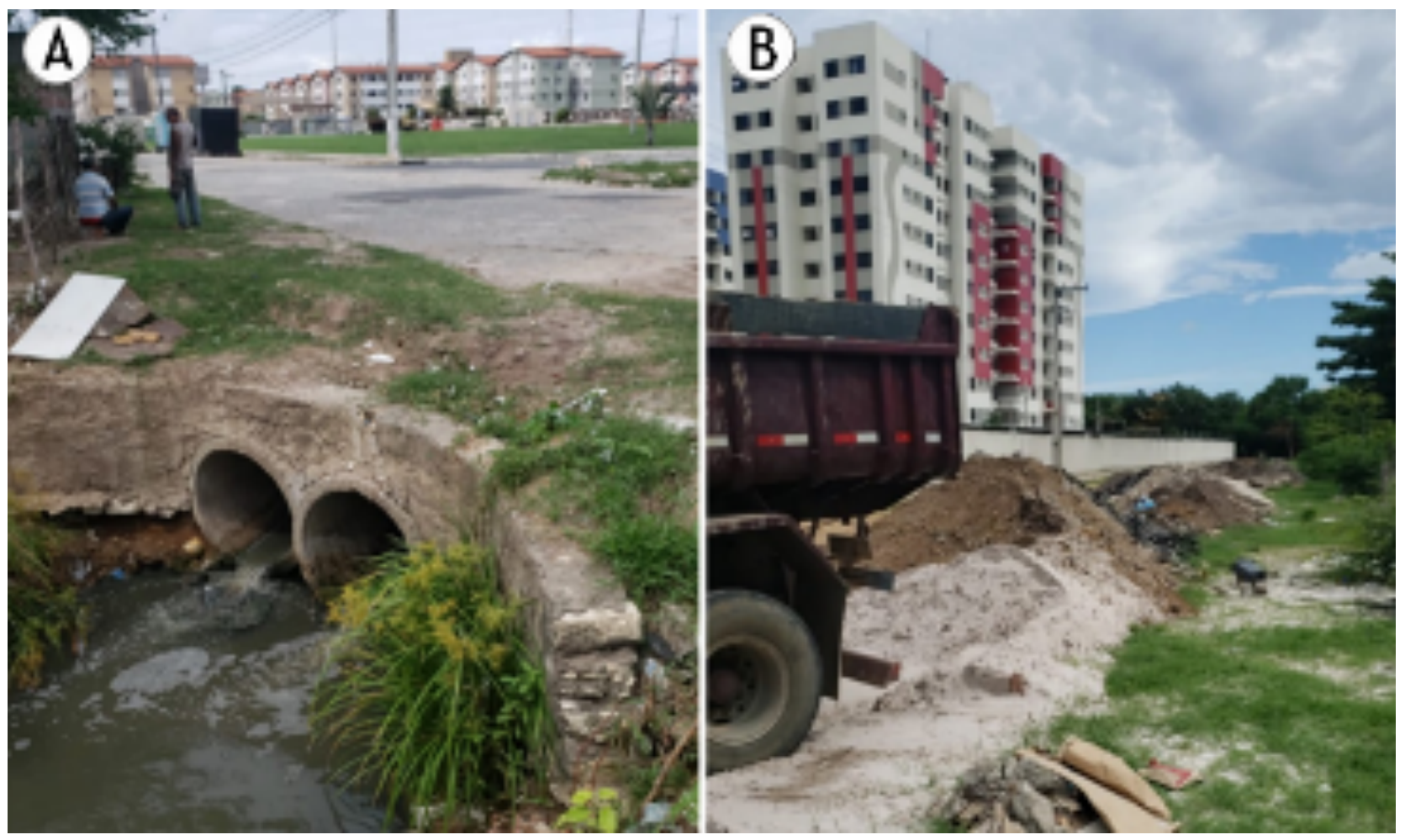

Os resultados do estudo de Santos (2015) sugerem que "os poluentes carreados pelas águas provindas do rio Poxim contribuam para a baixa qualidade ambiental do estuário, podendo ser agravado durante o período chuvoso".

Na UP 1, verificam-se edificações verticais multifamiliares, cuja localização encontra-se em áreas de APP. Encontra-se o Condomínio Vila Verde Jabotiana, no qual o muro atua como elemento delimitador do ambiente natural e construído. Ao lado do condomínio, há o registro de diversos resíduos sólidos descartados de maneira incorreta em áreas protegidas ambientalmente.

Na segunda UP, os condomínios que se encontram em áreas de APP e ficaram "ilhados" durante as fortes chuvas de julho de 2019. Essa UP é caracterizada por condomínios do Programa de Arrendamento Residencial - PAR e residências com condições precárias de infraestrutura. Desta forma, os moradores não tinham condições de deslocamento para outras áreas.

Percebe-se, portanto, principalmente, duas unidades de paisagem bem diversificadas, pois há áreas que não replicam o modelo (edificações verticais) utilizado pela construção civil. O primeiro destaque refere-se às ocupações irregulares (Unidade de Paisagem 2), localizadas a margem do rio Poxim (Figura 12).

Essas residências não proporcionam condições dignas de moradia e permitem que os moradores estejam sujeitos a doenças e acidentes. Nesse trecho, pode-se observar como o mercado imobiliário atua na formalização do espaço urbano, pois vizinho às ocupações formais encontramse os condomínios verticais Residencial Vila Velha e Residencial Santa Fé, beneficiados com infraestrutura básica. 
Figura 12. Ocupações irregulares às margens do rio Poxim, configurando a Unidade de Paisagem 2.

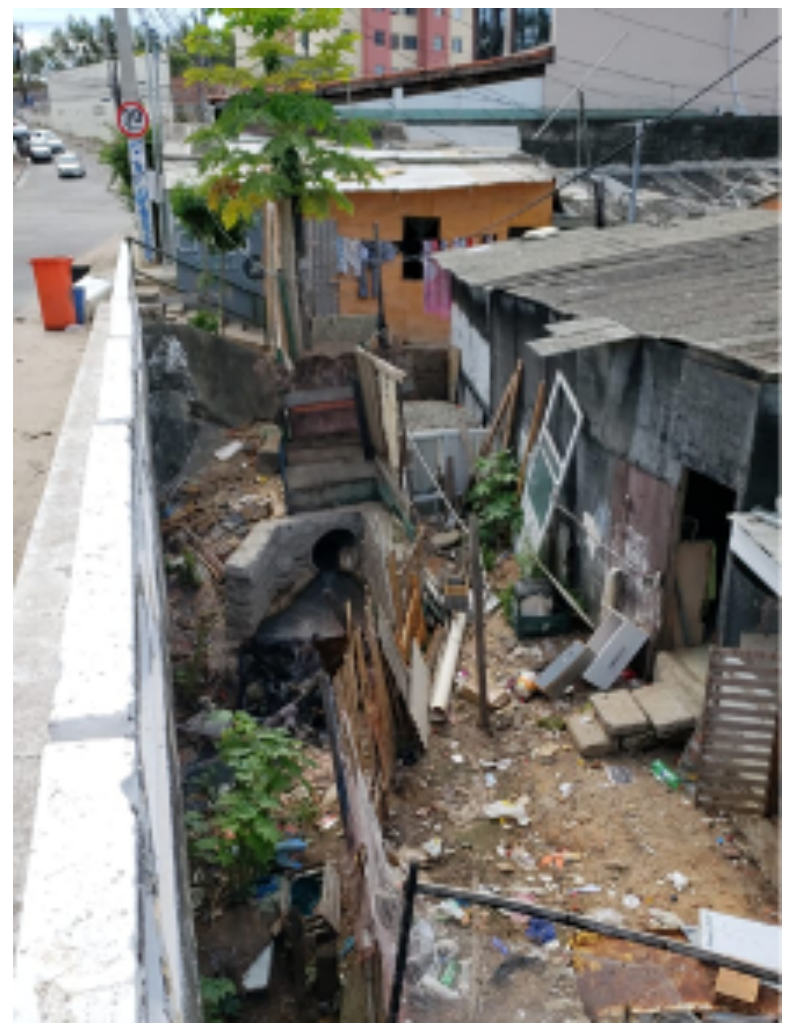

Fonte: Visitas técnicas, 2020.

Nota-se que as unidades I e II apresentam-se diversificadas em relação à composição da tipologia arquitetônica, entretanto, os problemas existentes são recorrentes a exemplo das ocupações em APP; baixa permeabilidade do solo; descarte incorreto de resíduos sólidos; e lançamento de efluentes diretamente no rio Poxim.

\section{Unidades de Paisagem 3 e 4}

Essas unidades encontram-se no bairro Inácio Barbosa que possui características distintas em relação à renda dos moradores. Segmentou-se a análise entre a comunidade Pantanal (classe com renda baixa - Unidade de Paisagem 3) e os outros conjuntos residenciais existentes (classe com renda média e alta), configurando a Unidade de Paisagem 4.

De acordo com a classificação da Secretaria de Assuntos Estratégicos (2012) e com Kamakura e Mazzon (2016), tomando por base o grau de vulnerabilidade, a população brasileira foi dividida em três grupos, com o propósito de maximizar a homogeneidade dentro de cada grupo, utilizando um critério denominado polarização: baixa, média e alta.

$\mathrm{Na}$ Unidade de Paisagem 3, representada pela comunidade Pantanal, a faixa de residências localizadas em áreas destinadas às APP é composta por edificações horizontais e unifamiliares. Algumas ruas não possuem pavimentação e a delimitação entre o ambiente construído e natural se dá por um pequeno muro de contenção.

Além das residências da comunidade Pantanal, encontram-se também em áreas destinadas às APP, edificações residenciais de classe média, configurando a Unidade de Paisagem 4 (Figura 13). 
Figura 13. Residências de classe média situadas em áreas destinadas às Áreas de Preservação Permanente (APPs).

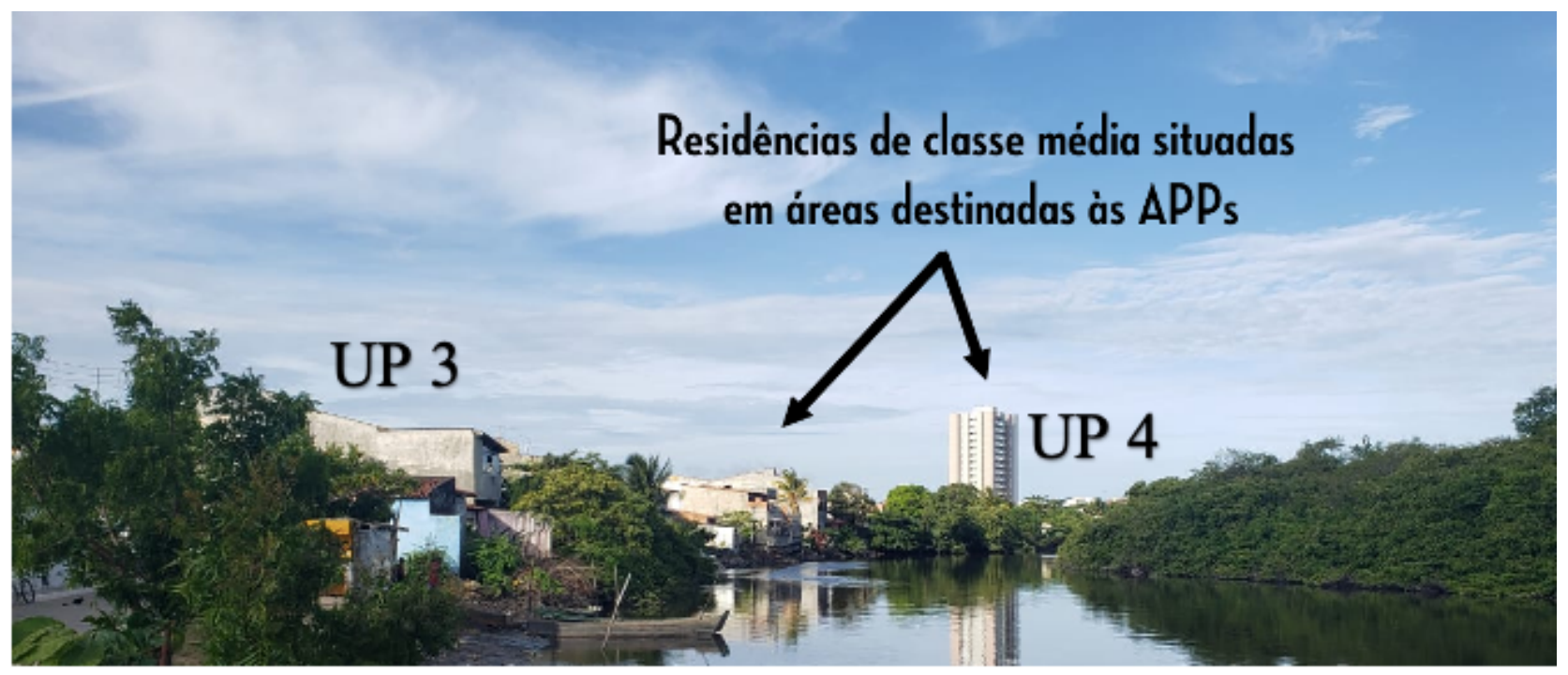

Fonte: Visitas técnicas, 2020.

As construções, citadas anteriormente, também refletem pressões antrópicas no meio ambiente. Desta forma, como elemento minimizador da alteração da paisagem natural e fazendo com que ocorra a preservação do patrimônio, foi criado o Parque Natural Municipal do rio Poxim que é uma Unidade de Conservação de Proteção Integral, formada pelos bairros: Inácio Barbosa, São Conrado e Farolândia. No trecho do bairro Inácio Barbosa, referente à unidade de Conservação, observou-se um alto descarte incorreto de resíduos sólidos.

Nota-se que, mesmo com ações do poder público para minimizar os impactos antrópicos no meio ambiente, o bairro apresentou problemas como ocupações das APP e descarte incorreto de resíduos sólidos.

\section{Unidade de Paisagem 5}

Apesar de ser um trecho curto, apresenta o maior grau de urbanização e estruturação de Aracaju, os moradores dessa unidade possuem uma classe de renda média e alta. As áreas destinadas às APP foram substituídas por construções de tipologia comercial (lojas de automóveis e posto de gasolina) conforme a Figura 14, e institucional (Parque Augusto Franco, popularmente conhecido como Parque da Sementeira, e Associação de Engenheiros Agrônomos de Sergipe - AEASE).

Ainda consta nesse trecho a Companhia de Desenvolvimento dos Vales do São Francisco e do Parnaíba - CODEVASF, Empresa Brasileira de Pesquisa Agropecuária - EMBRAPA, e edificações residenciais de alto padrão como Edifício Beira Mar, Mansão Cidade de Lisboa, Mansão Seixas Dória, Ville de Paris e Mansão Cartier). Alguns deles, a exemplo do Parque da Sementeira e AEASE estão localizados em áreas destinadas às APPs. 
Figura 14. Ocupação do solo com a tipologia comercial no Unidade 5.

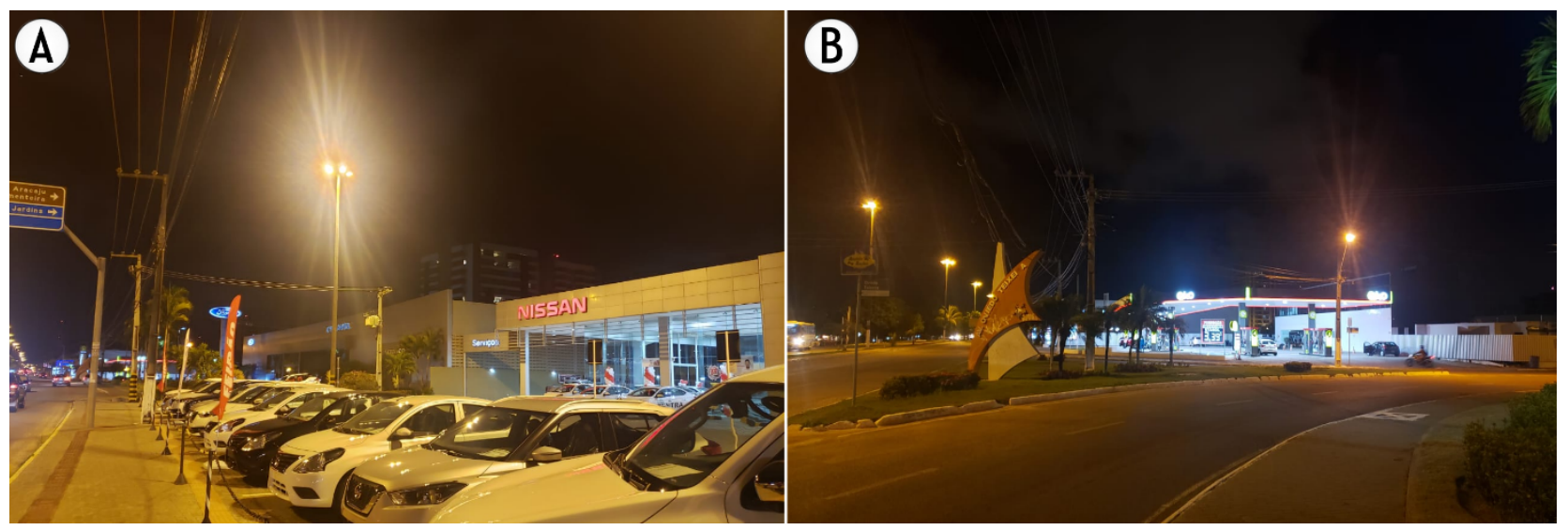

Fonte: Visitas técnicas, 2020.

Unidade de Paisagem 6

Diferente da unidade analisada no item anterior, a UP 6 é bastante heterogênea, principalmente no tocante às condições de renda da população residente. Outra característica observada é que parte da faixa destinada às APP está ocupada por edificações, cujas tipologias são comerciais ou residenciais e unifamiliares (Figura 15), caracterizando essa UP.

Figura 15. Tipologias habitacionais existentes na Unidade de Paisagem 6.

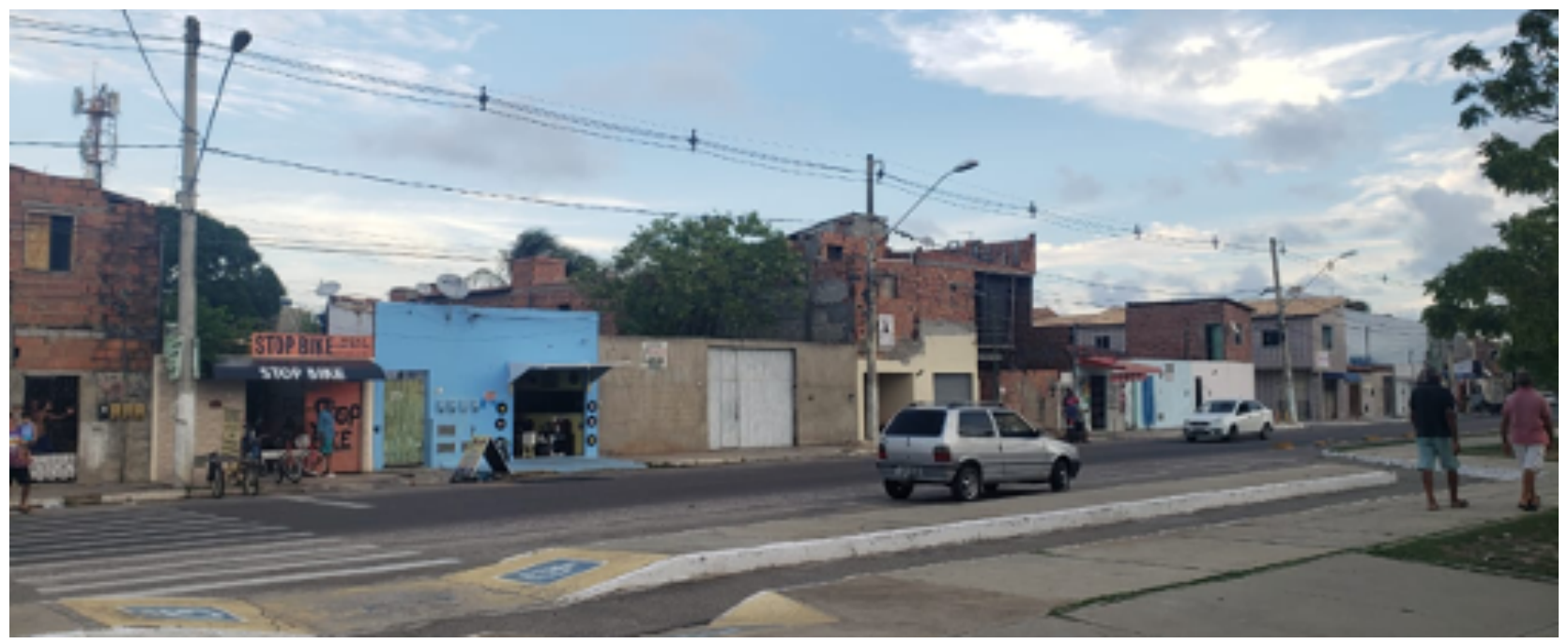

Fonte: Visitas técnicas, 2020.

Nessa faixa destinada às APP observou-se também que há um alto descarte incorreto de resíduos sólidos e os espaços públicos necessitam de reparos para que a população possa usufruir de práticas sociais individuais e/ou coletivas. Essa UP fica localizada no bairro Coroa do Meio. 
Unidade de Paisagem 7

Os acessos à faixa destinada para as APP, apesar de serem existentes nos mapas oficiais da Prefeitura de Aracaju, durante as visitas técnicas, não foram encontrados devido ao fechamento com os muros dos condomínios verticais existentes nessa unidade. Esses muros atuam como a divisão entre as áreas construídas e naturais, caracterizando a Unidade de Paisagem 7, que se localiza no bairro Farolândia.

Além disso, o trecho apresenta outras problemáticas inseridas nas APP, como queimadas, efluentes lançados diretamente no rio Poxim, descarte incorreto de resíduos sólidos e edificações (residenciais e comerciais) em áreas de APP conforme demonstra a Figura 16 A-B, a seguir:

Figura 16 A-B - Problemáticas encontradas na faixa de Área de Preservação Permanente da Unidade de Paisagem 7.

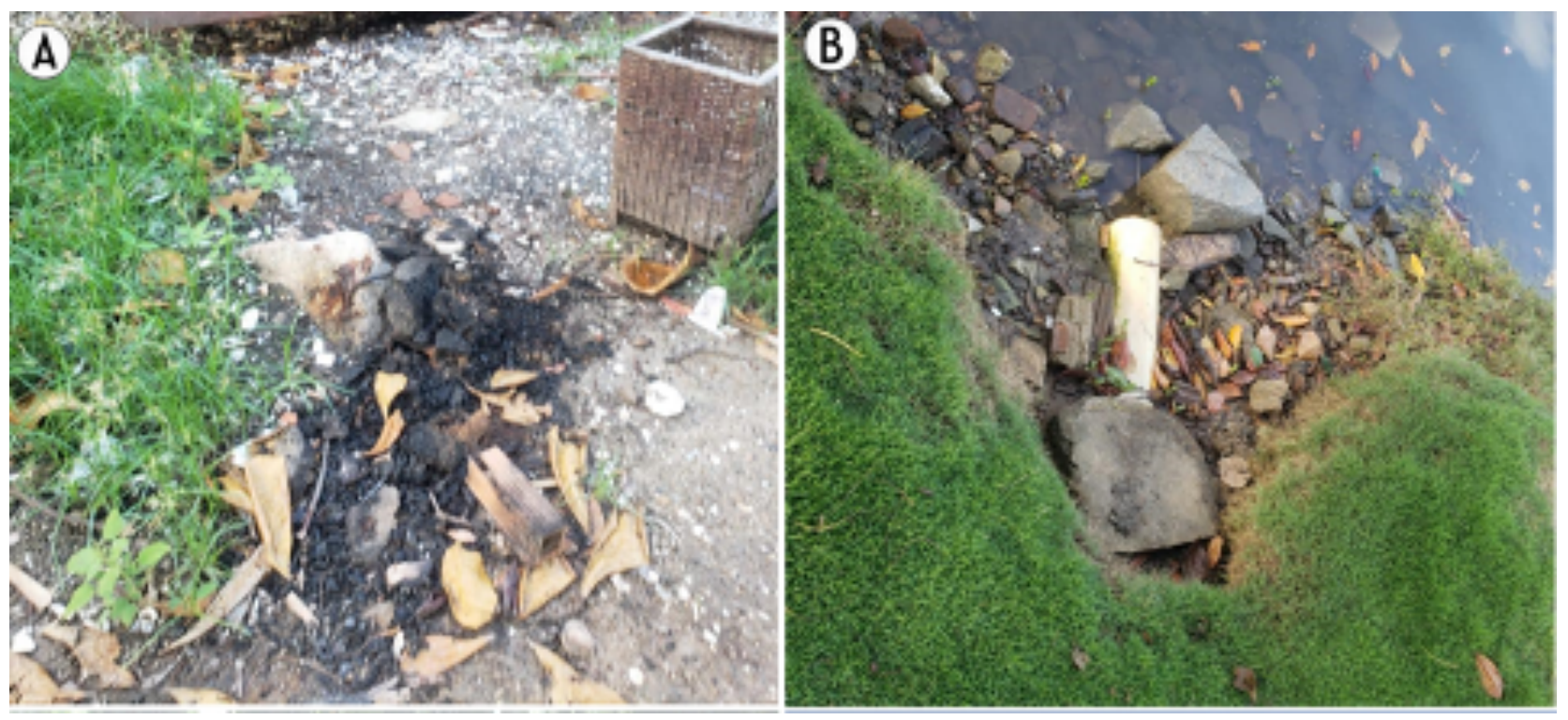

Fonte: Visitas técnicas, 2020.

Unidade de Paisagem 8

Na última UP notou-se que a retirada da vegetação destinada à faixa das APP é devido à construção de residências que estão situadas às margens do rio Poxim Essas construções apresentam problemas como lançamento de efluentes diretamente no rio Poxim e infraestrutura precária das edificações.

Outro problema apresentado no bairro foi a carência de áreas de recreação e lazer, por isso, a população improvisa locais que sirvam para os usos citados. Sugere-se a construção de parques lineares para a população.

Segundo Medeiros, Uliana e Araújo (2020), os projetos de parques lineares ao longo de cursos d'água podem ajudar na recuperação das margens que foram retificadas ou alteradas de alguma forma, e, além dos benefícios ecológicos, também trazem muitos benefícios para a recreação da população. No entanto, eles geralmente necessitam de grandes áreas verdes e investimentos, porém sua implantação é simples, sendo práticas possíveis de serem realizadas mesmo com as restrições existentes no meio urbano. No entanto, verifica-se que, no Brasil, poucos são os projetos de 
recuperação de rios urbanos que têm sido criados com a abrangência dos exemplos internacionais. Existe uma grande dificuldade na implantação das propostas no contexto nacional. Na maioria das vezes, os planos são implantados apenas parcialmente, devido à falta de investimentos e de vontade política.

Após analisar cada unidade, calculou-se o índice de uso e ocupação do solo (IUOS) a partir da relação entre total da área de APP $\left(6.852 .443,203 \mathrm{~m}^{2}\right)$ e área construída em APP $(1.036 .538,359$ m2), com dados da Prefeitura Municipal de Aracaju, 2020.

Através desse índice, confirma-se que 15\% das APP de todas as UPs estão ocupadas pela população e pelo poder público. Observando essa porcentagem, evidencia-se que há uma possível insustentabilidade ambiental urbana que afeta diferentes temáticas (social, ambiental e econômica) conforme Garcez e Carmello (2017, p. 127) afirmam que “[...] a sustentabilidade urbana não está restrita ao meio ambiente, abrangendo a expressão dos fatores econômicos, sociais, culturais e políticos".

Destarte, foi elaborado o Quadro 3 para sintetizar as fragilidades referentes aos trechos analisados nos municípios de Blumenau e o Quadro 4, referente aos trechos analisados do município de Aracaju, possibilitando assim, uma análise mais detalhada da situação das APP estudadas.

Quadro 3. Síntese das fragilidades existentes nas Unidades de Paisagens do Ribeirão Fresco, em Blumenau/ SC.

\begin{tabular}{|l|c|c|c|c|c|c|}
\hline \multicolumn{2}{|c|}{ TRECHOS ESTUDADOS } & UP 1 & UP 2 & UP 3 & UP 4 & UP 5 \\
\hline \multicolumn{7}{|c|}{ FRAGILIDADES } \\
\hline - Ocupações em áreas destinadas às APP & $\mathrm{X}$ & $\mathrm{X}$ & $\mathrm{X}$ & $\mathrm{X}$ & $\mathrm{X}$ \\
\hline - Cheias e enxurradas & $\mathrm{X}$ & $\mathrm{X}$ & $\mathrm{X}$ & $\mathrm{X}$ & $\mathrm{X}$ \\
\hline - Canalização & $\mathrm{X}$ & $\mathrm{X}$ & $\mathrm{X}$ & $\mathrm{X}$ & $\mathrm{X}$ \\
\hline - Retificação & $\mathrm{X}$ & $\mathrm{X}$ & $\mathrm{X}$ & $\mathrm{X}$ & $\mathrm{X}$ \\
\hline - Poluição dos cursos d'água & $\mathrm{X}$ & $\mathrm{X}$ & $\mathrm{X}$ & $\mathrm{X}$ & $\mathrm{X}$ \\
\hline - Retirada da mata ciliar & $\mathrm{X}$ & $\mathrm{X}$ & $\mathrm{X}$ & $\mathrm{X}$ & $\mathrm{X}$ \\
\hline - Existência de doenças e contaminações & $\mathrm{X}$ & $\mathrm{X}$ & $\mathrm{X}$ & $\mathrm{X}$ & $\mathrm{X}$ \\
\hline - Deslizamento de terra & - & - & - & $\mathrm{X}$ & $\mathrm{X}$ \\
\hline
\end{tabular}

Fonte: Visitas técnicas, 2019.

Quadro 4. Síntese das fragilidades existentes nas Unidades de Paisagens do Rio Poxim, em Aracaju/SE

\begin{tabular}{|l|c|c|c|c|c|c|c|}
\hline \multicolumn{2}{|c|}{ TRECHOS ESTUDADOS } & $\begin{array}{c}\text { UPs } \\
1 \text { E 2 }\end{array}$ & $\begin{array}{c}\text { UPs } \\
\mathbf{3} \text { E } 4\end{array}$ & UP 5 & UP 6 & UP 7 & UP 8 \\
\hline \multicolumn{7}{|c|}{ FRAGILIDADES } \\
\hline - Ocupações em áreas destinadas às APP & $\mathrm{X}$ & $\mathrm{X}$ & $\mathrm{X}$ & $\mathrm{X}$ & $\mathrm{X}$ & $\mathrm{X}$ \\
\hline - Retirada de vegetação nativa & $\mathrm{X}$ & $\mathrm{X}$ & $\mathrm{X}$ & $\mathrm{X}$ & $\mathrm{X}$ & $\mathrm{X}$ \\
\hline - Poucas áreas de lazer e recreação no bairro & $\mathrm{X}$ & $\mathrm{X}$ & - & - & - & $\mathrm{X}$ \\
\hline
\end{tabular}




\begin{tabular}{|l|c|c|c|c|c|c|c|}
\hline \multicolumn{2}{|c|}{ TRECHOS ESTUDADOS } & $\begin{array}{c}\text { UPs } \\
\text { 1 E 2 }\end{array}$ & $\begin{array}{c}\text { UPs } \\
\text { 3 E 4 }\end{array}$ & UP 5 & UP 6 & UP 7 & UP 8 \\
\hline \multicolumn{7}{|c|}{ FRAGILIDADES } \\
\hline - Efluentes lançados diretamente no rio Poxim & $\mathrm{X}$ & $\mathrm{X}$ & - & $\mathrm{X}$ & $\mathrm{X}$ & $\mathrm{X}$ \\
\hline - Descarte incorreto de resíduos sólidos & $\mathrm{X}$ & $\mathrm{X}$ & - & $\mathrm{X}$ & $\mathrm{X}$ & $\mathrm{X}$ \\
\hline - Equipamentos públicos deteriorados & & $\mathrm{X}$ & - & $\mathrm{X}$ & - & - \\
\hline
\end{tabular}

Fonte: Visitas técnicas, 2019.

\section{Conclusões}

Embora existam problemas semelhantes, o ponto comum das duas realidades é a ocupação urbana em APP. As análises apresentadas ao longo do artigo permitiram, além da compreensão das APP urbanas (e entorno) de cada local, elaborar uma síntese das fragilidades em relação à situação atual das Áreas de Preservação Permanente de Blumenau/SC e Aracaju/SE.

Para Blumenau/SC, através dessa ocupação, as pressões antrópicas tornaram-se maiores, cujas consequências foram expressas em problemas como enchentes, deslizamento de terra, descarte incorreto de resíduos sólidos, entre outros.

Para Aracaju/SE, as maiores fragilidades das UPs são semelhantes e destacam-se: a ocupação em áreas de APP; poucos ELs públicos voltados às práticas sociais; ausência de manutenção das áreas de lazer e recreação existentes; efluentes lançados diretamente no rio Poxim; e pouca/inexistência de fiscalização e sinalização para proteção de áreas frágeis ambientalmente.

Analisando os problemas socioambientais, comprovados através dessa pesquisa, nota-se que se faz necessária uma maior compreensão da importância dessas áreas protegidas juridicamente. Para isso, são necessários instrumentos que possibilitem minimizar as pressões antrópicas exercidas, através de políticas públicas que fomentem o beneficiamento socioambiental dessas áreas.

A partir dessa realidade, sugerem-se diretrizes a partir de 3 categorias: Reordenamento da ocupação urbana; Requalificação urbana e Preservação ambiental. Na primeira categoria, as ações estão associadas às maneiras que a ocupação urbana pode influenciar nas consequências socioambientais. Para isso, foi sugerido a revisão do PDDU de Aracaju (através de uma melhor avaliação do coeficiente de aproveitamento e da taxa de ocupação. Para ambos os casos, faz-se necessária a efetivação de medidas que evitem a especulação imobiliária; diversidade dos usos, entre outros), regularização fundiária e urbana; retirada de famílias de áreas de risco; e a indução do adensamento das áreas mais consolidadas e com infraestrutura, fazendo com desestimule a ocupação em áreas ambientalmente frágeis e/ou áreas sem infraestrutura.

$\mathrm{Na}$ segunda categoria encontra-se a Requalificação urbana, cujas medidas para as duas áreas são a revitalização de áreas degradadas em função da integração pessoa e ambiente; criação de ELs visando práticas sociais; e melhorias nos equipamentos urbanos. Na terceira e última categoria, as diretrizes são referentes à preservação ambiental, cujas ações são através da inserção de vias de contenção ao longo das APP; plantio de espécies nativas; sinalização e fiscalização das áreas frágeis ambientalmente e criação do circuito verde (parque linear visando proteger as APP, delimitar o espaço construído do natural e ampliar a integração entre pessoa e ambiente). 
A elaboração das diretrizes apresentadas baseou-se no entendimento das dinâmicas existentes em cada UP e nas múltiplas paisagens de cada uma, para isso, obteve como foco as relações dos usuários com o ambiente e o entendimento do local (que foram observados durante as visitas técnicas).

Conclui-se que atuar no processo de planejamento urbano sustentável significa criar (ou ressignificar) espaços que potencializem as relações da comunidade (entre si e entre o ambiente que vive), do ambiente natural, e do crescimento econômico através do uso e ocupação do solo bem estruturado que interliga essas relações e promove a dinâmica urbana.

\section{Agradecimentos}

Os autores agradecem ao coordenador geral do Projeto CERES: Conexões entre estudos regionais em perspectiva socioambiental (CAPES/FAPITEC-SE edital 10/2016), Prof. Dr. Roberto de Souza. Os autores também agradecem a bolsa CAPES Demanda Social do mestre BJM e da mestra ICSO e ao apoio institucional da Universidade Regional de Blumenau (FURB) e da Universidade Federal de Sergipe (UFS).

Participação dos autores: ICSO - revisão dos dados relativos à Sergipe, normatização do artigo; BJM - revisão dos dados relativos à Santa Catarina; CMMS - revisão dos dados relativos à Santa Catarina; PDA - coleta e análise de dados relativos à realidade de Santa Catarina; CNAJ, EVNL - coleta e escrita de dados relativos à realidade sergipana; JJC - revisão completa do artigo, normatização e submissão do artigo; RRS, RMS - revisão do trabalho.

Aprovação ética ou licenças de pesquisa: a coleta de dados dispensou a obtenção de licenças.

Disponibilidade dos dados: parte dos dados foram da Dissertação de BJM e estão disponíveis no repositório da BDTD (https://bdtd.ibict.br/vufind/Record/FURB_6ea382dee6c4f6b3cd978adf21611796). Outra parte refere-se a dissertação de ICSO, mas ainda não foi inserida no repositório da UFS.

Fomento: CAPES: Projeto CERES: Conexões entre estudos regionais em perspectiva socioambiental (CAPES/FAPITECSE edital 10/2016). BJL e ICSO receberam bolsa CAPES Demanda Social.

Conflito de Interesses: Os autores declaram não haver conflito de interesses.

\section{Referências}

Ana. 2019. Abastecimento Urbano de Água - Região Metropolitana de Aracaju. Disponível em: http://atlas.ana.gov.br/ atlas/forms/analise/RegiaoMetropolitana.aspx?rme=3. Acesso em: $10 \mathrm{dez} .2019$.

Araújo CC, Silva MSF. 2017. Os (des)Caminhos das Águas do Rio Poxim em Aracaju a partir da Percepção do Discente. DOI - 10.20396/sbgfa.vli2017.1974 - E-book - Geografia Física: Currículo, Formação e Práticas de Ensino.

Attanasio CM. 2018. Manual técnico: Restauração e Monitoramento da Mata Ciliar e da reserva legal para a Certificação Agrícola - Conservação da Biodiversidade na Cefeicultura. Piracicaba: Imaflora, 60p.

Barbosa VC, Júnior AT, Oliveira GM, Silva V. 2017. Contextualização da Paisagem no Bairro Ribeirão Fresco a partir da análise das dimensões da sustentabilidade de Sachs. Territórios, Redes e Desenvolvimento Regional: perspectivas e desafios, 1(1):1-5.

Brasil. 2002a. Resolução no 302, de 20 de março de 2002. Resolução Conama №302. Brasília, DF, 20 março 2002. Disponível em: http://www2.mma.gov.br/port/conama/legiabre.cfm?codlegi=298. Acesso em: 20 dez. 2019 
Análise das unidades de paisagem e implicações socioambientais em áreas de preservação permanente: estudo de caso em Blumenau (SC) e Aracaju (SE)

Brasil. 2002b. Resolução no 303, de 20 de março de 2002. Resolução Conama No303. Brasília, DF, 20 março 2002. Disponível em: http://www2.mma.gov.br/port/conama/legiabre.cfm?codlegi=299. Acesso em: 20 dez. 2019

Brasil. 2006. Resolução n 369, de 28 de março de 2006. Resolução Conama No369. Brasília, DF, 20 março 2006. Disponível em: http://www2.mma.gov.br/port/conama/legiabre.cfm?codlegi=489. Acesso em: 20 dez. 2019

Brasil. 2012. Congresso. Senado. Lei no 12.651, de 25 de maio de 2012. Lei № 12.651, de 25 de Maio de 2012. Brasília, DF, 25 maio 2012. Disponível em: http://www.planalto.gov.br/ccivil_03/_Ato2011-2014/2012/Lei/L12651.htm. Acesso em: 18 dez. 2018.

Cantuário VAP, Oliveira FS. 2020. Entre o Desmatamento e a Legislação: Questões a serem consideradas sobre a situação recente das Áreas de Preservação Permanente de Paragominas-PA. PRACS: Revista Eletrônica de Humanidades do Curso de Ciências Sociais da UNIFAP, 13(2):373-398.

Camargo A. 2018. Um modelo de gestão sustentável de parque linear para ser implantado no ribeirão fortaleza, em Blumenau, SC. Trabalho de Conclusão de Curso (Especialização em Gestão Pública). Escola Nacional de Administração Pública (Enap).

Carminatti KD. 2018. Cidade, apropriação e urbanidade: uma análise do traçado urbano de Blumenau como rede de espaços públicos. Curso de Arquitetura e Urbanismo. Universidade do Vale do Itajaí/SC.

Daiello CZ, Rempel C. 2020. Cenário das áreas de preservação permanente em propriedades rurais produtoras de leite no Vale do Taquari ante o Código Florestal. Sustainability in Debate, 11(1):33-50.

Dias DF, Trentin R, Sccoti AAV.2015. Zoneamento Geoambiental para o Município de Mata/RS: síntese das potencialidades e fragilidades. Revista do Departamento de Geografia, 30(4):132-148. DOI: https://doi.org/10.11606/rdg.v30i0.98406

Dias JR, Saad AR, Bau Dalmas F. 2020. Aplicação da Lei no 12.651/2012 na Análise da Ocupação das Áreas de Preservação Permanente da Bacia Hidrográfica Cachoeirinha Invernada, Guarulhos (SP). Revista Direitos Culturais, 15(36):193-207. DOI: https://doi.org/10.20912/rdc.v15i36.19

Facco J, Fujita C, Berto JL. 2014. Agroindustrialização e Urbanização de Chapecó-SC (1950 - 2010): uma visão sobre os impactos e conflitos urbanos e ambientais. Redes: Revista do Desenvolvimento Regional, 19(1):187-215.

Fernandes RD, Ramalho AMC, Rosa CC, Souza CMM, Mello BJ. 2020. Da Escassez ao Excesso de Água: um Recorte do Semiárido no Nordeste e Médio Vale do Itajaí no Sul do Brasil. Revista Brasileira de Geografia Física, 13(3):1263-1279.

Ferreira NH, Ferreira CABV, Gouveia ICMC. 2016. Mapa de Fragilidade Ambiental como auxílio para o Planejamento Urbano e Gestão de Recursos Hídricos. Revista Fórum Ambiental da Alta Paulista, 12(3):44-58. DOI: http://dx.doi.org/ $10.17271 / 1980082712320161411$

Ferreira RA, Aguiar Netto AO, Santos TIS, Santos BL, Matos EL. 2011. Nascentes da sub-bacia hidrográfica do rio Poxim, Estado de Sergipe: da degradação à restauração. Revista Árvore, 35(2):265-277.

Garcez GS, Carmello MVB. 2017. Estatuto da Cidade e Plano Diretor: instrumentos urbano-ambientais ao desenvolvimento de cidades sustentáveis com área de Zona Costeira. Revista Direito Ambiental e Sociedade, 7(2):119-143.

Gonçalves BV, Gomes LJ. 2014. Percepção ambiental de produtores rurais na recuperação florestal da sub-bacia hidrográfica do rio Poxim - Sergipe. Desenvolvimento e Meio Ambiente, 29(1):127-138. DOI: http://dx.doi.org/10.5380/ dma.v29i0.32327

IBGE. Instituto Brasileiro de Geografia e Estatística, 2010. Censo 2010. Disponível: https://www.ibge.gov.br/. Acesso: 10 out. 2018.

Kamakura W, Mazzon JÁ. 2016. Critérios de Estratificação e Comparação de Classificadores Socioeconômicos no Brasil. Revista de Administração de Empresas, 56(1):55-70. DOI: https://doi.org/10.1590/S0034-759020160106. 
Martins F, Freitas, AR. 2014. Identificação das unidades de paisagem na bacia hidrográfica do Arroio dos Pereiras, em Irati-PR. Perspectiva, Erechim, 38(143):39-49.

Medeiros JMM, Uliana BB, Araújo DS. 2020. Áreas de Preservação Permanente Urbanas e Parques Lineares na Região Norte: conflitos na Lagoa dos Índios, Macapá - Amapá. Risco - Revista de Pesquisa em Arquitetura e Urbanismo, 18(1):119. DOI: https://doi.org/10.11606/issn.1984-4506.v18i0p1-19.

Mello BJ. 2019. Avaliação de resiliência socioecológica como estratégia de gestão de risco a desastres socioambientais: o caso da Microbacia Hidrográfica do Ribeirão Fresco, Blumenau (SC). Dissertação (Mestrado em Desenvolvimento Regional) - Universidade Regional de Blumenau, Centro de Ciências Humanas e da Comunicação, Programa de PósGraduação em Desenvolvimento Regional. Blumenau/SC.

Oliveira AB, Silva FG, Arruda JM, França BB. 2020. Pesquisa e Extensão como Base para Construção de Saberes Ambientais: Oficina Colaborativa sobre Área de Preservação Permanente na Bacia do Ribeirão do Taquaruçu Grande. Revista Humanidades e Inovação, 7(8):412-433.

Oliveira DS. 2011. Resgate de técnicas construtivas mais sustentáveis: Análise e Descrição do Sistema Enxaimel. Dissertação (Mestrado em Engenharia Civil). Universidade Federal do Rio Grande do Sul, Porto Alegre.

Oliveira ICSO. 2020. Águas Urbanas: Áreas de Preservação Permanente (APP) do Rio Poxim em Aracaju/SE. Dissertação (Mestrado em Desenvolvimento e Meio Ambiente). Universidade Federal de Sergipe. PRODEMA. São Cristóvão/SE.

PMB. Prefeitura Municipal de Blumenau, 2013. Perfil do bairro Ribeirão Fresco. Disponível: https://www.blumenau.sc.gov. br/governo/secretaria-de-desenvolvimento-urbano/pagina/historia-sobre-municipio/divisa-administrativabairros/ bairro-ribeirao-fresco-seplan. Acesso: 27 jun. 2019.

SAE. Secretaria de Assuntos Estratégicos, Presidência da República. (2012). Relatório de definição da classe média no Brasil. Recuperado de http://www.sae.gov.br/documentos/publicacoes/relatorio-de-definicao-da-classe-media-nobrasil/

Santana JP, Oliveira EVS, Dantas TVP, Landim MF, Rocha PA. 2020. Fitossociologia de manguezais em zonas urbanas: um estudo de caso em Aracaju, Sergipe. Revista Brasileira de Geografia Física, 13(5):2103-2113.

Santos AAO, Melo JBA, Nascimento MKS, Nilin J. 2015. Qualidade Ambiental do Estuário do Rio Poxim (Aracaju/ Sergipe): enfoque ecotoxicológico. II Congresso Internacional RESAG. Aracaju/SE.

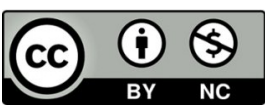

Esta obra está licenciada com uma Licença Creative Commons Atribuição Não-Comercial 4.0 Internacional. 